\title{
Flux estimates of isoprene, methanol and acetone from airborne PTR-MS measurements over the tropical rainforest during the GABRIEL 2005 campaign
}

\author{
G. Eerdekens $^{1,2}$, L. Ganzeveld ${ }^{1,3}$, J. Vilà-Guerau de Arellano ${ }^{3}$, T. Klüpfel ${ }^{1}$, V. Sinha ${ }^{1}$, N. Yassaa ${ }^{1,4}$, J. Williams $^{1}$, \\ H. Harder ${ }^{1}$, D. Kubistin ${ }^{1}$, M. Martinez ${ }^{1}$, and J. Lelieveld ${ }^{1}$ \\ ${ }^{1}$ Max Planck Institute for Chemistry, Air Chemistry, Joh.-Joachim-Becher-Weg 27, 55128 Mainz, Germany \\ ${ }^{2}$ Research Group Plant and Vegetation Ecology, Department of Biology, University of Antwerp, Universiteitsplein 1, \\ 2610 Wilrijk, Belgium \\ ${ }^{3}$ Department of Environmental Sciences, Wageningen University and Research Centre, Droevendaalsesteeg 4, \\ 6708 PB, Wageningen, The Netherlands \\ ${ }^{4}$ Faculty of Chemistry, Houari Boumediene University of Science and Technology, BP 32 El-Alia, \\ Bab-Ezzouar 16111, Algiers
}

Received: 16 May 2008 - Published in Atmos. Chem. Phys. Discuss.: 8 July 2008

Revised: 11 June 2009 - Accepted: 11 June 2009 - Published: 1 July 2009

\begin{abstract}
Tropical forests are a strong source of biogenic volatile organic compounds (BVOCs) to the atmosphere which can potentially impact the atmospheric oxidation capacity. Here we present airborne and ground-based BVOC measurements representative for the long dry season covering a large area of the northern Amazonian rainforest $\left(6-3^{\circ} \mathrm{N}, 50-59^{\circ} \mathrm{W}\right)$. The measurements were conducted during the October 2005 GABRIEL (Guyanas AtmosphereBiosphere exchange and Radicals Intensive Experiment with the Learjet) campaign. The vertical ( $35 \mathrm{~m}$ to $10 \mathrm{~km})$ and diurnal (09:00-16:00) profiles of isoprene, its oxidation products methacrolein and methyl vinyl ketone and methanol and acetone, measured by PTR-MS (Proton Transfer Reaction Mass Spectrometry), have been used to empirically estimate their emission fluxes from the forest canopy on a regional scale. The mixed layer isoprene emission flux, inferred from the airborne measurements above $300 \mathrm{~m}$, is $5.7 \mathrm{mg}$ isoprene $\mathrm{m}^{-2} \mathrm{~h}^{-1}$ after compensating for chemistry and $\sim 6.9 \mathrm{mg}$ isoprene $\mathrm{m}^{-2} \mathrm{~h}^{-1}$ taking detrainment into account. This surface flux is in general agreement with previous tropical forest studies. Inferred methanol and acetone emission fluxes are $0.5 \mathrm{mg}$ methanol $\mathrm{m}^{-2} \mathrm{~h}^{-1}$ and $0.35 \mathrm{mg}$ acetone $\mathrm{m}^{-2} \mathrm{~h}^{-1}$, respectively. The BVOC measurements were compared with fluxes and mixing ratios simulated with
\end{abstract}

Correspondence to: G. Eerdekens (williams@mpch-mainz.mpg.de) a single-column chemistry and climate model (SCM). The inferred isoprene flux is substantially smaller than that simulated with an implementation of a commonly applied BVOC emission algorithm in the SCM.

\section{Introduction}

Tropical forest ecosystems are important sources (and sinks) for many gas and aerosol species, producing almost half of the estimated $1.3 \mathrm{PgC} \mathrm{yr}^{-1}$ globally emitted biogenic volatile organic compounds (BVOCs) (Guenther et al., 1995; Guenther, 2002). The total BVOC budget is estimated to comprise of: $44 \%$ isoprene, $11 \%$ monoterpenes, $22.5 \%$ other reactive VOCs, and $22.5 \%$ other VOCs (e.g. methanol and acetone). Global atmospheric chemistry models rely on emission inventories to provide accurate fluxes of BVOCs. Such emissions vary as a function of many parameters e.g. temperature, light, species, age etc. (e.g. Monson et al., 1992; Kesselmeier and Staudt, 1999) and hence are subject to large uncertainty due to enormous species diversity, uncharacterised landscapes and limited datasets.

Recently, a new parameterised inventory named the Model of Emissions of Gases and Aerosols from Nature (MEGAN) (Guenther et al., 2006), has been developed to better quantify net terrestrial biosphere BVOC emissions. Leaf area index and plant functional type are among the

Published by Copernicus Publications on behalf of the European Geosciences Union. 
parameters considered within MEGAN to simulate BVOC emissions. The annual global isoprene emission estimated with MEGAN, ranges from about 500 to $750 \mathrm{Tg} \mathrm{C} \mathrm{yr}^{-1}$, depending on the applied input data. Like isoprene, acetone and methanol are also strongly emitted by terrestrial vegetation but their budgets are currently not well constrained (Galbally and Kirstine, 2002; Jacob, 2002). Therefore a comparison of modelled and in situ measured values is helpful in assessing our current understanding of BVOC fluxes. A further motivation for such comparisons is that the oxidation chemistry of BVOCs over low $\mathrm{NO}_{\mathrm{x}}$ tropical ecosystems is currently not well understood (Lelieveld et al., 2008), and again by comparison the measured values with various model simulations possible causes for discrepancies can be investigated.

In this study we present in situ airborne measurements of BVOCs for the long dry season in October 2005, monitored by a Proton Transfer Reaction Mass Spectrometer (PTR-MS) together with other trace gases over Guyana's tropical rainforest. Most notable within the context of this study, are the observations of hydroxyl $(\mathrm{OH})$ and hydroperoxy $\left(\mathrm{HO}_{2}\right)$ radicals, reactive oxidized nitrogen $\left(\mathrm{NO}_{\mathrm{x}}\right)$ and ozone $\left(\mathrm{O}_{3}\right)$, during the GABRIEL (Guyana's Atmosphere-Biosphere exchange and Radicals Intensive Experiment with the Learjet) campaign. The GABRIEL campaign was a successor to the LBA/CLAIRE (Large-scale Biosphere-Atmosphere experiment) which was conducted in the short dry season in March 1998 (e.g. Williams et al., 2001). The main focus of GABRIEL was to quantify $\mathrm{OH}$ and key BVOC species over the Amazonian rainforest and to compare these values to those simulated by state of the art models. Ten flights were performed between $300 \mathrm{~m}$ to $10 \mathrm{~km}$ altitude, at different times of day and extents of rainforest influence, providing a data set suitable for studying horizontal, vertical and diurnal cycles over the pristine rainforest. This large scale approach is inherently less prone to scaling errors than single leaf or tower based studies (Greenberg and Zimmerman, 1984; Rinne et al., 2002; Greenberg et al., 2004a; Karl et al., 2004). The spatial and temporal distribution in the observed mixing ratios of isoprene, methacrolein, methyl vinyl ketone, methanol and acetone have been used together with an empirically derived convective boundary layer (CBL) height (or "mixing height") to estimate their emission fluxes as a function of time. These inferred fluxes, vertical profiles and diurnal cycles for these species are then compared with those simulated with a Single-Column atmospheric chemistry and climate Model (SCM). The SCM has been applied previously to interpret GABRIEL campaign observations of boundary layer meteorology and ozone and $\mathrm{NO}_{\mathrm{x}}$ atmosphere-biosphere exchange (Ganzeveld et al., 2008). It is used here to complement our analysis of BVOC observations as a function of transport and chemistry in the CBL.

Several recent papers have reported large discrepancies between measured and modelled isoprene concentrations in the tropics (Ehhalt and Prather, 2001; von Kuhlmann et al., 2004; Jöckel et al., 2006). These discrepancies seem to occur in all these model simulations despite the use of well established isoprene emission algorithms (Guenther et al., 1995, 2006). A more recent study by Karl et al. (2007) reported agreement between observed direct flux measurements and the MEGAN model predictions, suggesting that the fluxes of BVOC into photochemical models are better represented than the chemistry schemes currently used. The SCM, a state-of-the art chemistry-transport model was applied in this study to aid interpretation of the observations by exploring the effect on chemistry of varying emission rates and to provide information regarding parameters that were measured during the GABRIEL campaign.

The following analysis of the GABRIEL data is structured as follows: an introduction of the site characteristics and meteorology; experimental details and the SCM description. Subsequently, an analysis of the observed and simulated vertical profiles and diurnal cycles in BVOC mixing ratios is presented as well as an assessment of chemical and mixing timescales. Finally, the results of, rainforest emission flux calculation for isoprene, acetone and methanol from observed mixing ratios are shown and comparisons with modelled data discussed.

\section{Site description and meteorology}

Meteorological conditions over the northeast coast of South America are strongly influenced by the annual migration of the Inter-Tropical Convergence Zone (ITCZ). Two rainy and two dry seasons can be distinguished, and the long dry season takes place from mid August until November. In October 2005 the ITCZ was located north of Suriname at approximately $10-15^{\circ} \mathrm{N}$. Although geographically in the Northern Hemisphere, the Guyana's were located in the atmospheric Southern Hemisphere, under the influence of the south-easterly trade winds. At the surface, the trade winds advected clean marine boundary layer air westwards over the pristine tropical rainforests of French Guyana and Suriname.

Despite the fact that GABRIEL was conducted during the dry season, meteorological observations indicated that the region was still relatively moist with short rain showers occurring almost daily, subsequent to the development of shallow cumuli in the afternoon and increased cloudiness towards the evening. The low level cloud base over land during the GABRIEL-campaign varied from $300-550 \mathrm{~m}$ in the morning, to $900-1200 \mathrm{~m}$ in the afternoon (based on visual, civil aircraft and satellite observations). The cloud cover was comparable over Suriname and French Guyana throughout the campaign; generally building up to 3 octas, and occasionally 5 octas in the afternoon (Scheeren et al., 2007). Cloud shadows reduce the upward heat flux from the surface into the atmosphere (Schumann et al., 2002) as well as the lightdependent trace gas emissions. The average surface temperature for October 2005 was $33^{\circ} \mathrm{C}$ and the relative humidity generally varied between $\sim 70 \%$ (morning) and $\sim 50 \%$ (afternoon) with surface easterlies of $5-6 \mathrm{~m} / \mathrm{s}$. 


\section{Experimental set-up}

During the GABRIEL campaign measurements were performed from on-board a Learjet (35A) to monitor the distribution of species vertically $(300 \mathrm{~m}-10 \mathrm{~km})$, and horizontally (range ca. $1800 \mathrm{~km}$ ) by day. Morning-, noon- and late afternoon flights were performed to examine the regional diurnal variations within the boundary layer and to a lesser extent the free troposphere. Details on the airborne instrumentation for the measurements of $\mathrm{CO}_{2}, \mathrm{H}_{2} \mathrm{O}, \mathrm{CO}, \mathrm{O}_{3}, \mathrm{NO}$, $J \mathrm{NO}_{2}, \mathrm{H}_{2} \mathrm{O}_{2}$, total peroxides, $\mathrm{OH}, \mathrm{HO}_{2}, \mathrm{HCHO}$, besides VOCs can be found elsewhere (Stickler et al., 2007; Martinez et al., 2008). The measurement of volatile organic compounds by the airborne proton transfer reaction mass spectrometer (PTR-MS) are described here, whereas VOCs measured with Thermo Desorption-Gas chromatography - Mass Spectrometry (TD-GCMS) and halogenated VOC canister GC-MS analysis are described by Williams et al. (2007) and Gebhardt et al. (2008), respectively. A second PTR-MS was sited in the forest approximately central in the measurement region (Brownsberg, Suriname) to provide $24 \mathrm{~h}$ ground level data for comparison with the aircraft (Sinha et al., 2008).

\subsection{Proton transfer reaction mass spectrometer (PTR-MS)}

The PTR-MS technique, described in detail elsewhere, (de Gouw and Warneke, 2007) and references therein, has been employed to measure several mass to charge ratios $(\mathrm{m} / \mathrm{z})$ $69,71,33,59$ and 42 which have been attributed to protonated isoprene, the sum of methacrolein and methyl vinyl ketone, methanol, acetone and acetonitrile respectively. These identifications are consistent with previous studies although minor contributions from other isobaric compounds, such as protonated propanal to $\mathrm{m} / \mathrm{z} 59$ (Lindinger et al., 1998; Williams et al., 2001) and fragments of 2-methyl-3-buten-2ol (MBO) to $m / z 69$ (Eerdekens, 2001; de Gouw et al., 2003a) cannot be ruled out.

\subsubsection{Airborne instrumentation}

A main flow of more than $10 \mathrm{~L} \mathrm{~min}^{-1}$ was drawn through a $9 \mathrm{~mm}$ I.D forward facing Teflon fast flow inlet (length $\sim 30 \mathrm{~cm}$ ) coupled inside the aircraft to a $6.35 \mathrm{~mm} \mathrm{I.D}$ (length $1 \mathrm{~m})$ Teflon tube. From the fast flow inlet, the PTR-MS system drew a flow of between $1.5 \mathrm{~L} \mathrm{~min}^{-1}$ at ground level to $150 \mathrm{ml} \mathrm{min}^{-1}$ at $10 \mathrm{~km}$, through $2.5 \mathrm{~m}$ of $3.18 \mathrm{~mm}$ I.D. Teflon tubing. A fraction of this flow was sampled at between 25$30 \mathrm{ml} \mathrm{min}^{-1}$ directly into the drift tube. Measurements were done under isobaric and isothermal conditions for the drift tube. The drift tube pressure was set at $2.2 \mathrm{mbar}$ and was automatically adjusted to its set point value in flight. The drift tube was temperature controlled to $40^{\circ} \mathrm{C}$ when the cabin air was sufficiently cool. However, under the extremely hot cabin temperatures which were often experienced at the end

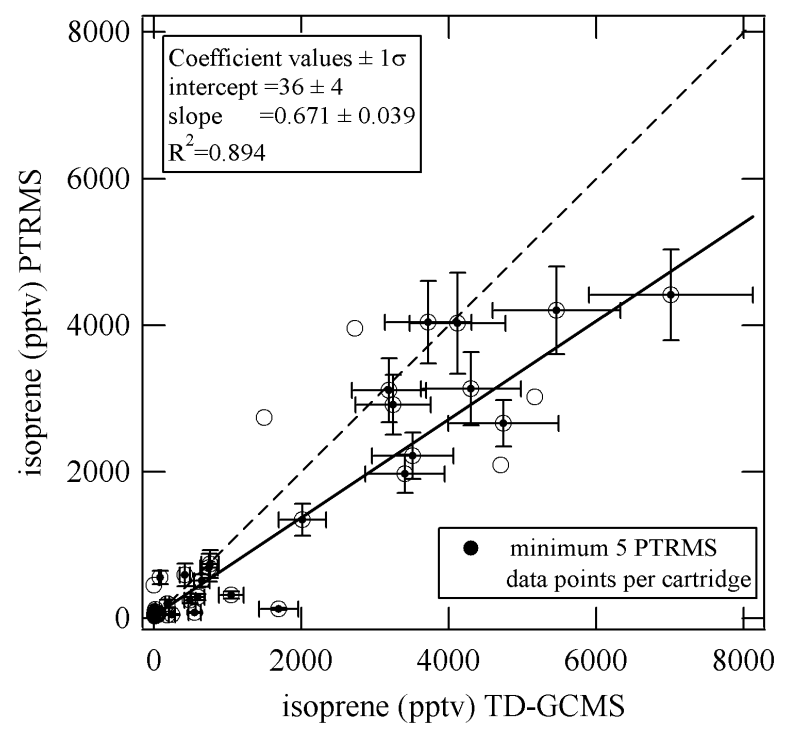

Fig. 1. Orthogonal distance regression of PTR-MS vs. TD-GCMS. Error bars represent the total measured uncertainty for each measurement technique within each interval of comparison.

of the flights this was not possible. Under such circumstances the drift tube temperature has been assumed to be equal to the cabin for the calculation of concentration. Data were obtained from 8 of the 10 flights. The time resolution was almost $30 \mathrm{~s}$ with dwell times of $0.9-2 \mathrm{~s}$ per mass. The average airspeed of the Learjet above the rainforest was $\sim 128 \pm 6 \mathrm{~m} / \mathrm{s}$.

\subsubsection{Ground-based measurements}

The ground based site (Brownsberg National Park, Suriname) was located in the middle of the operational area of the aircraft, which ranged from $6^{\circ}-3.5^{\circ} \mathrm{N}$ and $57^{\circ}-50^{\circ} \mathrm{W}$. The Brownsberg measurement site $\left(4^{\circ} 53^{\prime} \mathrm{N}, 55^{\circ} 13^{\prime} \mathrm{W}\right)$ was situated on the Mazaroni Plateau ca. $450 \mathrm{~m}$ above the surrounding lowlands and adjacent to a $55 \times 40 \mathrm{~km}^{2}$ lake situated east of the measurement site. Upwind from the site is 250-300 km of pristine rainforest before the coast of French Guyana.

An existing radio communication tower situated in a jungle clearing served as a stand for the inlet line. A membrane pump was used to draw air down from canopy top level $(\sim 35 \mathrm{~m})$ through a $50 \mathrm{~m}$ PFA tubing $(6.35 \mathrm{~mm}$ I.D.) to the instrument operated at $2.1 \mathrm{mbar}, 45^{\circ} \mathrm{C}$ for the drift tube. The main flow was restricted to $5 \mathrm{~L} \mathrm{~min}^{-1}$ mainly by a $5 \mu \mathrm{m}$ Teflon filter. The PFA tubing was shrouded with black tubing to minimise the potential of photochemically induced artefact signals. Continuous monitoring of the aforementioned BVOCs by PTR-MS (time resolution of $2 \mathrm{~min}$ ) at the ground based site was only possible for $\sim 3$ days starting from the 3 of October until the 6 of October from midday to midday. 


\subsubsection{Calibration}

Both PTR-MS instruments were calibrated in the field against the same gravimetric prepared synthetic mix (ApelRiemer Environmental, Inc., Denver, USA) comprising 13 non-methane hydrocarbons in the order of $\sim 500 \mathrm{ppbv}$ per substance, stated accuracy 5\%. This standard was diluted dynamically for calibration with synthetic air to achieve atmospheric mixing ratios (covering ppbv to pptv levels). In-field and post-flight calibrations started and ended with measurements of synthetic air cleaned by passing it through a catalytic converter. The catalytic converter (Platinum on quartz wool at $360^{\circ} \mathrm{C}$ ) stripped the air of organics and converting them to $\mathrm{CO}_{2}$ and $\mathrm{H}_{2} \mathrm{O}$ so as to provide a background signal. The difference between the sample and background signals was used to determine the mixing ratios present in the ambient air.

Subsequent to the campaign, humidity controlled calibrations were performed in the laboratory. The corrections for humidity driven sensitivity changes led to a small decrease in the mixing ratios for isoprene (2.7\% to $9.1 \%$ ), MACR+MVK $(6.1 \%-12.3 \%)$, methanol $(19.3 \%$ to $28.5 \%)$ and acetone $(<1 \%)$. Although the calibration factor for methanol over the humidity interval $20 \%-100 \%$ changed only a little, for dry conditions its calibration factor was substantially lower. The effect was smaller for acetonitrile (5.5 to 7\%). Similar effects were found for the ground-based instrument.

The precision or statistical uncertainty in the volume mixing ratio was calculated conservatively using Gaussian error propagation. The overall accuracy of the determination depends on the accuracy of each signal used in the calculation and their respective systematic errors. Reported values should be accurate to within 5-10\% assuming no unaccounted-for systematic errors are present and using the stated accuracy of the calibration standard and measurements of calibrated instrument response. The total measurement error (calculated as the geometric sum of accuracy and precision) for the airborne instrument for isoprene ranged from $25 \%$ (at $0.5 \mathrm{ppbv}$ ), and $8 \%$ (at $6 \mathrm{ppbv}$ ). For MACR+MVK volume mixing ratios between 0.4 and $2.5 \mathrm{ppbv}$ the corresponding total measurement errors were between $20 \%$ and $9 \%$. For acetone the total measurement errors were 25$10 \%$, for measurements ranging between $0.4-1.5 \mathrm{ppbv}$; and 50-20\% for methanol between 2-6 ppbv. If noise at each channel is taken as the signal observed upon sampling zero air (sampling with a catalytic converter in-line), the detection limits for the unsmoothed data using a threshold signalto-noise ratio of three were $0.27 \mathrm{ppbv}$ (methanol), $0.07 \mathrm{ppbv}$ (acetonitrile), $0.09 \mathrm{ppbv}$ (acetone), $0.10 \mathrm{ppbv}$ (isoprene) and 0.09 ppbv (MVK).

\subsection{Measurements of VOCs by TD-GCMS}

Airborne sampling of isoprene and monoterpenes over the tropical rainforest was performed using a custom built 18- cartridge sampling device installed within a standard aircraft wing pod. Within the wing pod, outside air was drawn by a metal bellows pump into the system. The sample tubes were fitted into the flowpath approximately $80 \mathrm{~cm}$ after the pump with Swagelok Ultra-Torr stainless steel fittings and sealed with 2-way electromagnetic valves at the entrance and the exit. To minimise the sample contamination from airport air, the pump was generally started $15 \mathrm{~min}$ after take-off. The sample tubes were fitted into the flow path after the pump and sealed with 2-way electromagnetic valves at the entrance and the exit.

Calibrated mass flow-controllers regulated the air flow through the system and a custom made process controller was used to set the parameters and record the sampling times. All pertinent sampling and analysis parameters and further details on the Thermo Desorption-GCMS system can be found in (Williams et al., 2007). Briefly, a stainless steel, two-bed sampling cartridge (Carbograph I and II) was filled every $10 \mathrm{~min}$ for $5 \mathrm{~min}$ continuous sampling (at least one blank was flown i.e. cartridge that was not opened in flight). Prior to flight, the cartridges were cleaned with the Thermoconditioner. Laboratory multipoint calibrations showed good linearity within the concentration ranges measured. Blanks, showed no high levels for the compounds discussed. Onepoint calibrations of VOC and of a terpene standard (both Apel-Riemer Environmental, Inc., Denver, USA, stated accuracy 5\%) were carried out at the beginning and the middle of each flight analysis. The total measurement uncertainties were around $15 \%$ and the detection limit ranged from 0.5 pptv to 5 pptv.

\subsection{Comparison PTR-MS - GCMS}

The number of PTR-MS data points that could be averaged over the 5 min sampling time of the cartridges varied because the PTR-MS periodically measured background values through the aforementioned catalytic converter. Therefore, a minimum threshold of 5 PTR-MS data points per cartridge was imposed for the intercomparison with the TD-GC-MS as presented in Fig. 1. The error bars show the total measurement uncertainty for isoprene. The y-axis error bars are calculated by the root mean square of the total measurement errors of all PTRMS data points within each interval. These total errors were found to be less than $16 \%$ for values higher than the median mixing ratios measured by the PTR-MS and $15 \%$ for the TD-GC-MS.

The orthogonal distance analysis expresses a linear relationship between the PTRMS and the TD-GCMS with a slope of 0.81 and an off-set of $34 \mathrm{pptv}\left(R^{2}=0.895\right)$. From all the diagnostic information we have on both measurement systems, no irregularities have been found. Since GC-PTRMS measurements were not performed, the relative contributions from known and unknown interferants (protonated molecules, or fragments e.g. from $m / z 87$ to $m / z 69$ ) could not be determined. Such interferences are assumed to be minor 


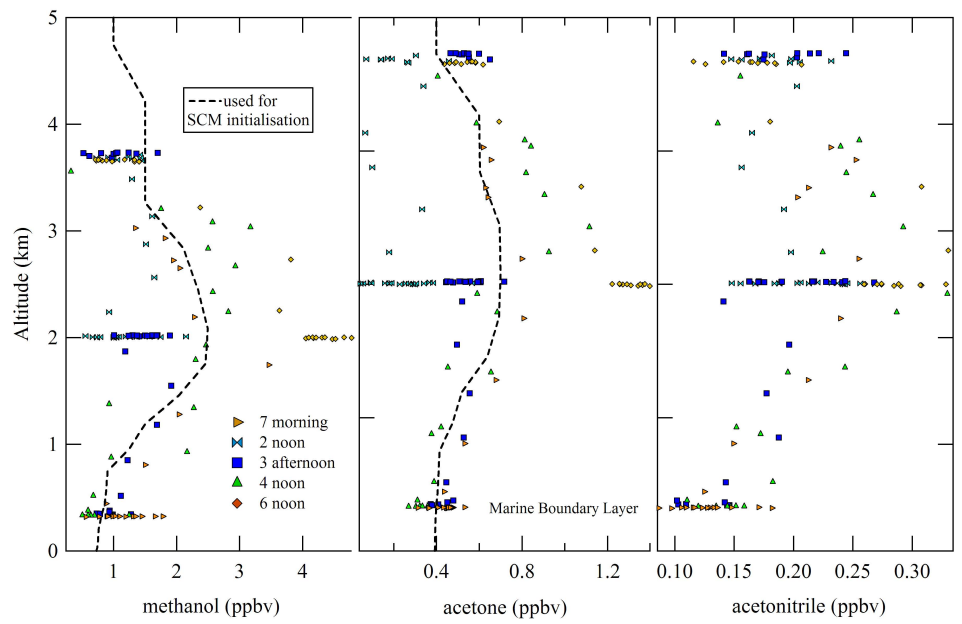

Fig. 2. Oceanic vertical profiles for methanol, acetone and acetonitrile used for SCM-model initialisation.

as isoprene will be most abundantly present over the tropical rainforest and the furan interferences from biomass burning were low.

The intercept is approximately zero in contrast to the isoprene inter-comparison for the LBA/CLAIRE campaign in 1998 (Warneke et al., 2001). In 2005, the cartridges were analysed immediately after each flight in order to minimise possible storage time artefacts. Storage tests on alkenes including isoprene captured in canisters have shown that the concentration of these species tend to grow after storage (Colomb et al., 2006), possibly explaining the larger 1998 offset. The high pumping rate through the wingpod system prevented the testing of sample integrity with a gas standard. If a reactive compound such as isoprene had been destroyed in the pump then isoprene would have been underestimated by the TD-GCMS analysis against PTR-MS and this was not observed.

As the inter-comparison of the GC and the PTR-MS is just within the stated uncertainties, we do not correct the PTRMS data in our subsequent calculations.

\section{SCM Model}

Since the Single-Column, chemistry climate Model has been described elsewhere (Ganzeveld et al., 2008 and references therein), only the salient features of the model are summarised below.

The SCM, as used in this study, included an explicit representation of atmosphere-biosphere trace gas exchanges using a multi-layer canopy exchanges model, distinguishing a crown- and understorey layer. It accounted for exchange processes and turbulence within the canopy as a function of the SCM's meteorological, hydrological and atmospheric chemistry parameters. In the default version, processes were resolved using, similar to the commonly applied vertical reso- lution of global models (e.g. ECHAM4/5), 19 layers (hereafter referred to as L19 version) from the surface up to $10 \mathrm{hPa}$ with 5 layers representing the daytime CBL. However, because of the demonstrated impact of a higher vertical resolution on tracer transport (Ganzeveld et al., 2008), the measurements were also compared with a 60 layer (L60) version of the SCM with 13 layers in the CBL.

The SCM's chemistry scheme is based on the CBM4 mechanism (Roelofs and Lelieveld, 2000 and references therein), and has been modified to include the oxidation of terpenes by ozonolysis (Ganzeveld et al., 2006) and $\mathrm{H}_{2} \mathrm{O}_{2}$ production through the formation and decomposition of long-chain hydroxyalkyl-hydroperoxides (ValverdeCanossa, 2004). For more details on $\mathrm{NO}_{\mathrm{x}}$ and ozone chemistry during the Gabriel campaign we refer to Ganzeveld et al. (2008).

Model simulations were performed in the "Lagrangian mode", which implies that during the simulations, the air column is advected from the Atlantic Ocean over the Amazon rainforest along a transect along $4.5^{\circ} \mathrm{N}$ from $45^{\circ} \mathrm{E}$ to $60^{\circ} \mathrm{E}$ at an average wind speed of $\sim 6 \mathrm{~m} / \mathrm{s}$, as observed within the PBL (see Fig. 2 in Gebhardt et al., 2008 for the vertical profiles for the wind direction and wind speed for the whole campaign). Modelled air masses were first advected over the ocean (1 day, 2 October) and then for 2 days over land (3-4 October), simulating the response of the column to changes in surface cover properties including the transition from an atmosphere-ocean to the atmospherebiosphere exchange regime. Land cover properties, NO and VOC emission factors were determined by the distribution of the 72 ecosystem classes of the Olson (1992) ecosystem database. Biogenic NO emissions were calculated according to Yienger and Levy (1995) whereas isoprene emissions were simulated using the MEGAN (Model of Emissions of Gases and Aerosols from Nature) algorithm (Guenther et al., 2006). 

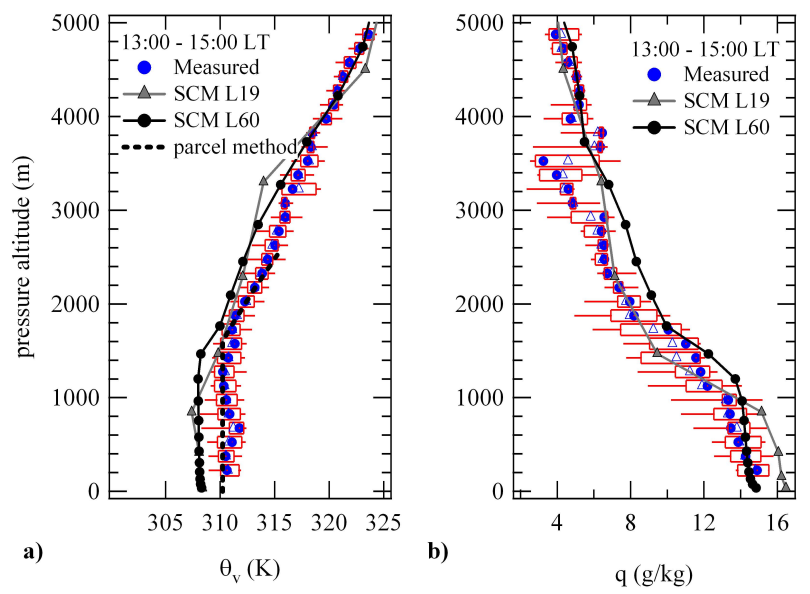

Fig. 3. Virtual potential temperature and specific humidity profiles between 13:00 and 15:00 gathered from several flights above the Guyana's rainforest in comparison to their SCM simulated profiles.

All other biogenic fluxes, including terpenes and oxygenated VOCs were based on an alternative algorithm. Since for methanol and acetone bi-directional exchanges have been observed (Karl et al., 2004), the exchange of these compounds in the SCM was simulated using a compensation point approach, in which the emission or deposition of a compound was calculated depending on leaf- and ambient air concentrations.

One particular feature of the model set-up relevant to the analysis presented here was an applied scaling of the online simulated isoprene emission flux. From the observations presented in this paper (see Sect. 5.7) we have inferred an isoprene emission flux which is apparently a factor 2 smaller than that calculated with the implementation of MEGAN in the SCM. It should be noted that isoprene simulated by the SCM according to Guenther et al. (1995) has been shown to be in good agreement with isoprene measurements from Manaus (Kuhn et al., 2007). Moreover a comparison of MEGAN driven modelled isoprene with the same measurement data from Manaus also yielded good agreement (unpublished results) without scaling. In order, to focus on the role of CBL transport and chemistry rather than differences between atmosphere-biosphere flux simulations, the SCM simulations based on a factor 2 decrease in simulated emissions were initially used for comparison with the measured results.

The North Atlantic oceanic vertical profiles of methanol and acetone were used to initialise the model at $45^{\circ} \mathrm{E}$ up to $5 \mathrm{~km}$ (see Fig. 2). Since isoprene mixing ratios over the ocean were close to or below the detection limit, its vertical initialisation profile was set to zero on all levels in the SCM. The reader is referred to Ganzeveld et al. (2008) for further details.

\section{Results and discussion}

\subsection{Observations and simulations of the CBL}

At the outset of this analysis it was important to characterise the evolution and structure of the CBL over the tropical forest, since the boundary layer dynamics control the dilution and vertical turbulent transport of the chemical species (see also Vilà-Guerau de Arellano et al., 2009) and hence the inferred emission fluxes.

Surface winds were rather constant (surface easterlies of $5-6 \mathrm{~m} / \mathrm{s}$ ) throughout the campaign, consistent with stable trade wind conditions. Figure 3 shows the characteristic thermodynamic vertical profiles during GABRIEL in 5-95 percentile box and whisker plots with highlighted means and medians (13-15 local time, LT=UTC -3$)$ for the virtual potential temperature $\left(\theta_{v}\right)$ and the specific humidity $(q) \theta_{v}$ was calculated according to Bolton (1980) from the static air temperature and $q$ was calculated from the measured water vapour mixing ratio using an NDIR absorption spectrometer (Gurk, 2003). The observed morning profiles of $\theta_{v}$ were typical for dry convective boundary layers without clouds and strong persistent winds above the CBL (marked by clear differences in temperature and humidity). The exchange of compounds with the atmosphere aloft occurs particularly when the CBL develops. The growth may continue in the afternoon or the CBL height may stabilize, depending on the synoptic conditions and surface buoyancy flux.

In the course of a typical day as clouds formed, the profiles of $\theta_{v}$ over the rainforest showed a conditionally unstable layer caused by the high moisture content, above the first virtual temperature inversion (see below). The sub-cloud layer buoyancy was driven by upward thermals, and in the cloud layer positive buoyant motions were caused by the release of latent heat from the condensation process. Both sub-layers are components of the CBL or mixed layer. As a result of the clouds, chemical compounds were transported to higher vertical heights compared to clear sky conditions, causing the CBL mixing ratios of emitted compounds to change (Schumann et al., 2002; Vilà-Guerau de Arellano et al., 2005). The clouds also acted to reduce radiation dependent biogenic emissions, photolysis rates and photochemical processes underneath (Lelieveld and Crutzen, 1991; Tang et al., 2003).

To support our analysis and to verify the occurrence of clouds, we have used a parcel method calculation. In short, a parcel is released with initial surface values $\theta_{v}=310.2 \mathrm{~K}$ and $q_{t}=16 \mathrm{~g} / \mathrm{kg}$ which follows a dry adiabatic until it condensates at the lifting condensation level (LCL: $1590 \mathrm{~m}$ ). Beyond this level the parcel follows a moist adiabatic. The results are shown in Fig. 3a, indicating a well-mixed sub-cloud layer below the LCL. By comparing the slope of the observed virtual potential temperature gradient with the moist adiabatic, we conclude that the stratification was conditionally unstable, characteristic for shallow cumuli. The analysis does not show a clear limit of free convection (LFC), which 

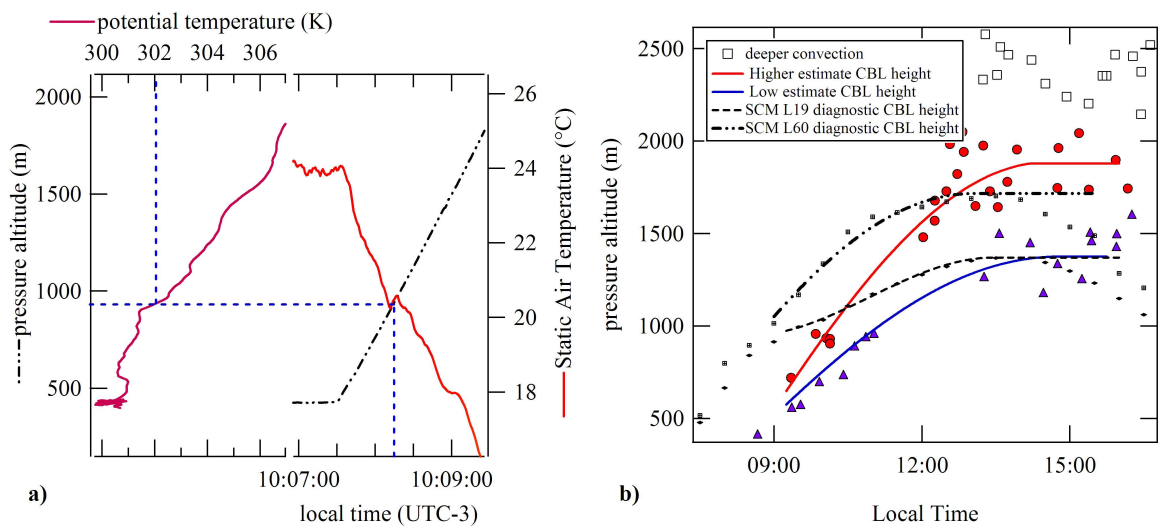

Fig. 4. (a) Fluctuation of the Static Air Temperature (SAT) upon constant climbing of the aircraft; (b) low and higher estimate of the CBL height evolution for the dry season (October) over the Guyana rainforest as explained in the text in comparison to that simulated by the (L19 and L60) SCM for the 1st day over land. The different markers represent the different inversions encountered in the vertical.

may indicate that the cloud extension could be higher than $5000 \mathrm{~m}$. It should be noted that the aforementioned situation was not in a steady-state and important processes like horizontal and vertical advection have been ignored. However, the parcel method allows us to get a better insight into the significance of shallow cumuli cloud in boundary layer evolution during the Gabriel campaign (Siebesma et al., 2003; Vilà-Guerau de Arellano, 2007).

In order to determine the CBL height over the rainforest as a function of time inversions (fluctuations) in the static air temperature measured on-board the aircraft have been examined. An example of one such capping inversion (at $941 \mathrm{~m}$ ) is shown in Fig. 4a, while Fig. 4b shows all observations. Data from coastal areas, ( $25 \mathrm{~km}$ from the coastline), were omitted in these estimates (see next section). Note there are several inversions present in most vertical profiles and these inversions generally occur at comparable levels above the rainforest for a particular time of day.

It was determined empirically that between 09:00 and 15:00 LT the boundary layer over the forest grew from $\sim 500$ to $\sim 1450 \mathrm{~m}$ (1st inversion, blue triangles in Fig. $4 \mathrm{~b}$ ) by applying a sinusoidal fit and a 5th order polynomial fit for undisturbed conditions. Both fits reproduce a diurnal cycle in boundary layer height with realistic boundary layer growth rates. The uncertainty in the boundary layer height estimate was directly related to the scatter and the number of observed temperature inversions. However, in many cases several inversions were present beyond the 1 st inversion above the rainforest, marking a 2nd inversion (red circles in Fig. 4b) with maxima at around $1900 \mathrm{~m}$ and another at around $2550 \mathrm{~m}$ (open squares in Fig. 4b) in the afternoon. Note that due to the partial cloud cover, the boundary layer height may not have been uniform over the entire domain. Weather observations by Scheeren et al. (2007) report higher altitude scattered clouds which could be passive remnants that are no longer connected to the boundary layer and occasionally there may have been clouds up to the $2.5 \mathrm{~km}$ altitude.
The observationally inferred boundary layer evolution compared reasonably well with the findings of Krejci et al. (2005), for the same area during LBA-CLAIRE 1998 and by Martin et al. (1998), who investigated the regions of Manaus further inland. Both reported boundary layer heights of 1200-1500 $\mathrm{m}$ and a cloud base of 1600-1800 $\mathrm{m}$ altitude.

Comparison of the observed and simulated boundary layer evolution for the first day over land shows that the SCM simulated boundary layer growth rates (for the L19 and L60 version) which were larger in the early morning, and smaller between 09:00 and 14:00 LT, compared to the observations (see Ganzeveld et al., 2008 for details on the SCM boundary layer representation). The difference between the observed and simulated boundary layer representation was likely due to different potential temperature lapse rates. Note that the SCM could only be provided with very limited ECMWF data over the Tropics. Observations showed a 3-4 K higher virtual potential temperature for an observed specific humidity between 14 and $16 \mathrm{~g} / \mathrm{kg}$ throughout the day below $1000 \mathrm{~m}$. The SCM L19 and L60 versions simulated initial (morning) higher boundary layer moisture contents $(16-17 \mathrm{~g} / \mathrm{kg}$ ) which did not decrease in the L19 version but which decreased by almost $2 \mathrm{~g} / \mathrm{kg}$ in the L60 version over the course of the day. The water vapour was transported deeper in the L60 troposphere, resulting in an improved agreement between the simulated and observed moisture content in the afternoon. However, it results in a slightly wetter and cooler layer between $1.5 \mathrm{~km}$ and $3.5 \mathrm{~km}$ compared to observations. The sensitivity of the boundary layer evolution to the potential temperature lapse rate for the GABRIEL conditions has been discussed by Vilà-Guerau de Arellano et al. (2009).

The depth of the marine boundary layer (MBL) is not expected to vary much over the course of the day. The observed inversions occurred at $\sim 460 \mathrm{~m}$ pressure altitude at 08:30, around $575 \mathrm{~m}$ around noontime, and at $\sim 500 \mathrm{~m}$ around 15:15. The observed MBL depth was therefore a little less than the simulated MBL depth $(\sim 640 \mathrm{~m})$. 


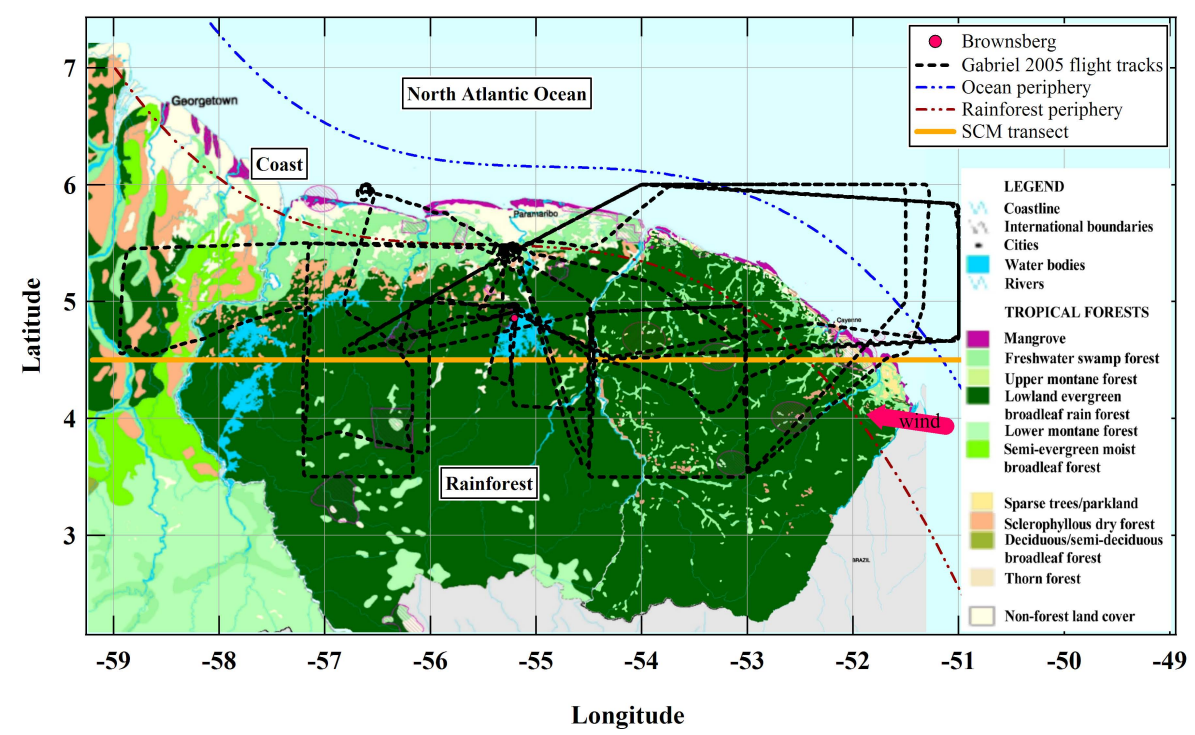

Fig. 5. Map of the geographical area over which the flights were conducted, superimposed onto a vegetation map (UNEP-WCMC, 2000)

\subsection{Data selection criteria}

BVOC emissions are inherently highly variable, being a function of plant type, solar intensity, temperature and other factors. In order to present the flight data as clearly as possible and to ensure a fair comparison with the simulated fluxes and CBL concentrations, a number of geographical, temporal and altitude filters have been applied. The intention was to reduce the possibility masking trends in the dataset. Details of each filter applied are presented below.

Biogeographical filter: a vegetation map of SouthAmerica (Eva et al., 2004) was used to filter only data collected over rainforested regions for analysis. The northernmost $100 \mathrm{~km}$ of Suriname is covered along the coast by mangrove forest), fresh water swamp forest (wetland forest) and cultivated crops and non-forest land cover (UNEP-WCMC). Data from this region have been filtered out so as to leave only rainforested areas under analysis (see Fig. 5). The total rainforested area under investigation was approx. $775 \mathrm{~km}$ by $220 \mathrm{~km}$.

Vertical filter: data were also filtered for the time evolution of the CBL height as discussed in the section on the GABRIEL 2005 boundary layer conditions. Hereafter, only data within the mixed layer are retained.

Temporal filter: to ensure fluxes were derived from airmasses that had spent the entire daylight period over the rainforest, the "startpoint" of the measured air parcel at sunrise (ca. 06:25) was calculated based on the specific wind direction and wind speed measured by the aircraft. If the airmass at dawn, for a certain data point measured in flight, was situated above the Atlantic Ocean or the coastal periphery, the data point was not considered.
The remaining post-filter data points were deemed to reflect the rainforest emissions into air masses crossing the forested region between dawn and the moment of measurement, and were characterised by their Forest Contact Time (FCT) with the Guyana's rainforest. The FCT has been defined as the time an air parcel spends in the CBL above the rainforest starting from the rainforest's periphery near the east coast of French Guiana. For this study, we focus on a transect which corresponds to the distance over the rainforest covered by an air mass between sunrise and sunset. The column of air was advected with an average speed of $5.4 \mathrm{~m} / \mathrm{s}$ over the rainforest, being exposed to the surface emissions between the east coast of French Guiana and the eastern shore of the reservoir $\left(54.9^{\circ} \mathrm{W}\right)$. This transect will be referred to as "the first day over land". Filtered data are used to infer the diurnal cycle of BVOCs above the rainforest and will be compared to the simulated diurnal cycle for the $3 \mathrm{Oc}-$ tober.

\subsection{Isoprene chemistry}

Isoprene is oxidised in the air, primarily by $\mathrm{OH}$. Main sources of $\mathrm{HO}_{\mathrm{x}}\left(\mathrm{OH}+\mathrm{HO}_{2}\right)$ are photolysis of ozone, formaldehyde and higher aldehydes whereas main sinks are the reaction with $\mathrm{CO}$, methane and isoprene emitted from the rainforest, forming methacrolein (MACR), methyl vinyl ketone (MVK) and formaldehyde as first order products (Carter and Atkinson, 1996).

Isoprene chemistry for low- $\mathrm{NO}_{\mathrm{x}}$ conditions is still poorly understood (Paulson and Seinfeld, 1992) but several studies e.g. (Montzka et al., 1993; Goldan et al., 1995; Biesenthal et al., 1998; Stroud et al., 2001) have shown that ambient $\mathrm{NO}_{\mathrm{x}}$ levels can influence the relationship between isoprene and 


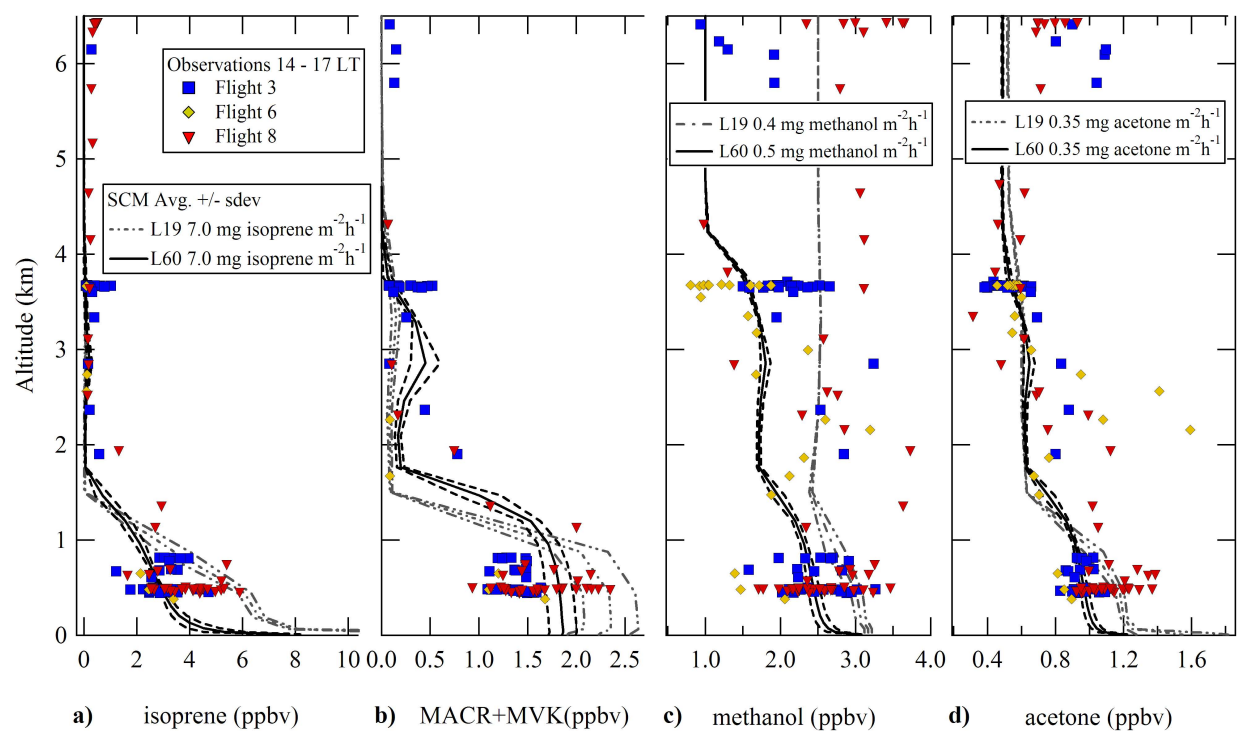

Fig. 6. Measured and modelled vertical profiles for isoprene, the sum of methacrolein and methyl vinyl ketone, methanol and acetone over the rainforest for the first day over land.

MACR+MVK (see also Sect. 5.6). Laboratory studies have shown that in the absence of NO, oxidation product yields of MACR and MVK are $22 \%$ and $17 \%$ respectively and $34 \%$ for formaldehyde in addition to organic hydroperoxides (Miyoshi et al., 1994; Benkelberg et al., 2000). Slightly different but comparable yields for MACR/MVK were obtained by Ruppert and Becker (2000) $(17.8 \% / 15.3 \%)$ and Lee et al. (2005) (19.0\%/14.4\%). Ruppert and Becker (2000) indicated that small amounts of methanol may be formed as a primary product from the $\mathrm{OH}$-initiated oxidation of isoprene under low $\mathrm{NO}_{\mathrm{x}}$. As $\mathrm{NO}$ was found to be generally less than 40 pptv during the GABRIEL campaign (Ganzeveld et al., 2008), isoprene oxidation was expected to produce MACR and MVK with a yield resembling that for the low $\mathrm{NO}_{\mathrm{x}}$ studies. This is important for this analysis since the isoprene flux was inferred using a chemically conservative tracer derived from the measured mixing ratios of isoprene, MACR and MVK. For this study we assume a summed MACR and MVK product yield of 39\% (note that the chemistry scheme in the SCM assumed a 55\% yield).

\subsection{Mixing ratio vertical profiles}

Isoprene and MACR+MVK mixing ratios decreased with increasing altitude, reflecting the role of photo-oxidation chemistry and mixing (Fig. 6a and b). In order to compare surface layer and mixed layer isoprene mixing ratios, a correction for chemical loss was required (as discussed in further detail below). The vertical profiles show that isoprene was well mixed in the boundary layer, with average mixing ratios of $3.2 \pm 1.0(1 \sigma) \mathrm{ppbv}$ for isoprene itself and $1.5 \pm 0.3 \mathrm{ppbv}$ for the photo-oxidation products MACR+MVK between 14:00 and 17:00 LT below $1.5 \mathrm{~km}$.
Enhanced isoprene and MACR+MVK mixing ratios observed above $\sim 1500 \mathrm{~m}$ altitude were most likely a result of convection associated with the shallow cumuli clouds. During flight 6 , the upward transport appeared to be limited to a smaller vertical domain compared to the other flights possibly due to differences in land-atmosphere interactions and cloud cover conditions.

The afternoon mixed layer average isoprene mixing ratio for GABRIEL was comparable to the $3.3 \mathrm{ppbv}$ obtained by Warneke et al. (2001) over the southern part of Suriname during LBA-CLAIRE 1998 though less than the $5.2 \mathrm{ppbv}$ average observed further inland near Manaus (Karl et al., 2007), and the $6.7 \mathrm{ppbv}$ measured in the mixed layer over Jaru (Rondônia) by Greenberg et al. (2004).

Figure 6 shows for comparison in situ measurements with simulated vertical profiles of BVOCs for the L19 and the L60 versions. It is clear that the L19 (with 5 layers representing the $\mathrm{CBL}$ ) version of the SCM version underestimates the vertical mixing within the CBL resulting in an overestimation of surface layer mixing ratios. It can also be inferred from Fig. 6 that isoprene mixing ratios simulated with the $\mathrm{L} 60$ version (with about 13 layers representing the CBL) was in better agreement with observations. Furthermore, the enhanced resolution resulted in well mixed profiles and convective transport beyond the clear sky boundary layer height $(\sim 1500 \mathrm{~m})$. The discrepancies between the model simulated and observed profiles were much smaller in the morning and early afternoon when clouds and convection were not yet playing an important role (see diurnal cycles in next section). Furthermore, the agreement in the morning was also likely due to a better agreement between simulated and observed $\mathrm{OH}$-concentration in the PBL due to relatively large 


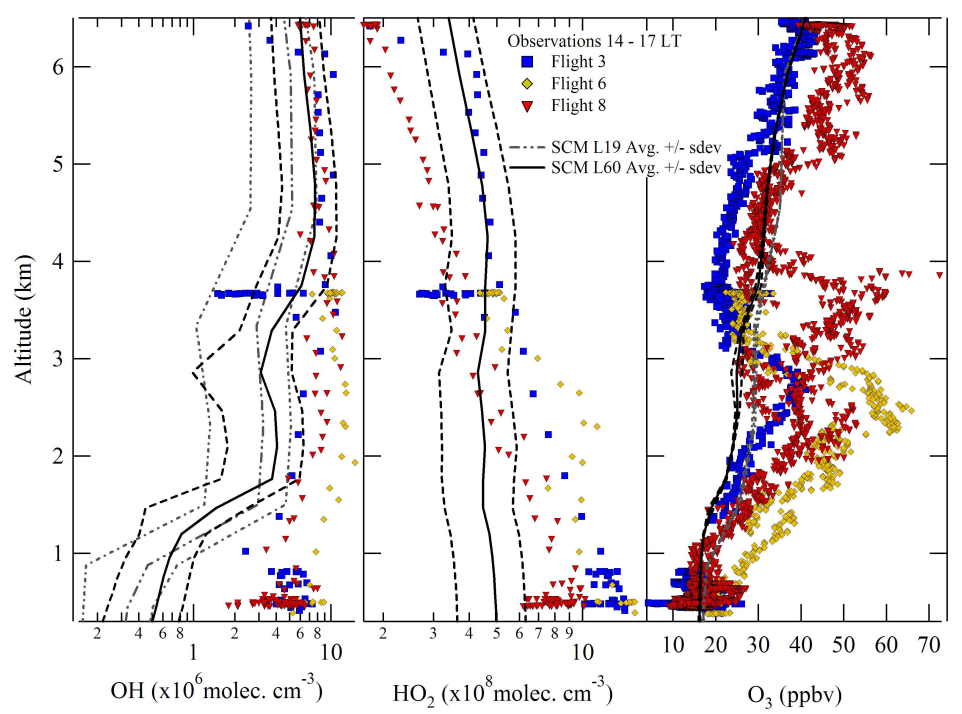

Fig. 7. Measured and modelled vertical profile of $\mathrm{OH}, \mathrm{HO}_{2}$ and $\mathrm{O}_{3}$ over the Tropical rainforest.

$\mathrm{NO}_{\mathrm{x}}$ mixing ratios associated with the accumulation of soilbiogenic $\mathrm{NO}_{\mathrm{x}}$ in the nocturnal inversion layer.

Less steep vertical mixing ratio profiles have been observed for methanol and acetone. These species are less reactive towards $\mathrm{OH}$ and $\mathrm{O}_{3}$ and can therefore serve to interpret the role of transport in and above the CBL for conditions with no significant influence of biomass burning (Lelieveld et al., 2008). Low acetonitrile mixing ratios of generally 100 to 300 pptv - except of flight 6 and 7 for which local acetonitrile mixing ratios reached a maximum of 450 pptv between 2 and $3 \mathrm{~km}$ - confirm the low impact of biomass burning emissions during the measurement period. Acetonitrile mixing ratios were only slightly elevated between 1 and $3.5 \mathrm{~km}$ over the ocean on a few flights as shown in Fig. 2. Observed decreases in marine boundary layers' mixing ratios are probably due to an oceanic uptake of methanol (Williams et al., 2004; Sinha et al., 2007), acetone (Marandino et al., 2005) and acetonitrile (Hamm et al., 1984; de Gouw et al., 2003b).

Figure $6 \mathrm{c}$ and $\mathrm{d}$ showS well mixed methanol and acetone profiles over the rain forest reflecting surface emissions and turbulent transport in the boundary layer. The average mixing ratios below $3 \mathrm{~km}$ were $2.4 \pm 0.5(1 \sigma)$ ppbv for methanol and 1.0 $\pm 0.2 \mathrm{ppbv}$ for acetone between 14:00 and 17:00 LT. The methanol values reported here are therefore significantly higher than the average value of $1.1 \mathrm{ppbv}$ from the 1998 LBA-CLAIRE campaign over the same height range (0$3 \mathrm{~km}$ ). In contrast, the 2005 acetone data reported here are significantly lower than the $2.7 \pm 0.8$ ppbv reported for 1998 .

Since methanol and acetone have relatively long atmospheric lifetimes it is important to consider their background oceanic mixing ratios for the initialization of the SCM (see Fig. 2). This initialization resulted in simulated acetone and methanol in reasonable agreement with the observations after more than one day of transport over the ocean before arriving at sunrise at the coast $\left(\sim 51.5^{\circ} \mathrm{E}\right)$. The simulated vertical profiles, in particular those for the L60 version, are in good agreement with the observations as a consequence of the deeper CBL and more efficient upward transport compared to the L19 version. Increasing the vertical resolution within the boundary layer of the model effectively reduced the boundary mixing ratios by about $30 \%$ between $09: 00$ and 16:00 LT.

The simulated vertical profile of ozone, relevant to the interpretation of the $\mathrm{HO}_{\mathrm{x}}$ concentration profiles, is in reasonable agreement with the observations though the SCM underestimates the ozone mixing ratios between 2 and $3.5 \mathrm{~km}$. The $\mathrm{OH}$ and $\mathrm{HO}_{2}$ profiles in Fig. 7 show that observations exceed the simulated $\mathrm{OH}$-concentrations by an order of magnitude. Increasing the vertical resolution within the SCM and consequently influencing the transport of trace gases and water vapour results in an increase in $\mathrm{OH}$ and $\mathrm{HO}_{2}$. The production of $\mathrm{HO}_{2}$ and $\mathrm{OH}$ (and its recycling) was much stronger in the boundary layer (and up to $3 \mathrm{~km}$ ) and has been discussed in more detail in Ganzeveld et al. (2008) and in Kubistin et al. (2008).

\subsection{Mixing ratio diurnal cycles}

To infer the area-average diurnal cycle in BVOCs, all mixed layer mixing ratios from the airborne observations were used after filtering according to the data selection criteria presented in Sect. 5.2. Restricting the dataset to the first day over land has the advantage of avoiding influences of residual layers from previous days (discussed in next section and in Ganzeveld et al., 2008). Since the aircraft sampled over undulating terrain (particularly south of $5^{\circ} \mathrm{N}$, with 


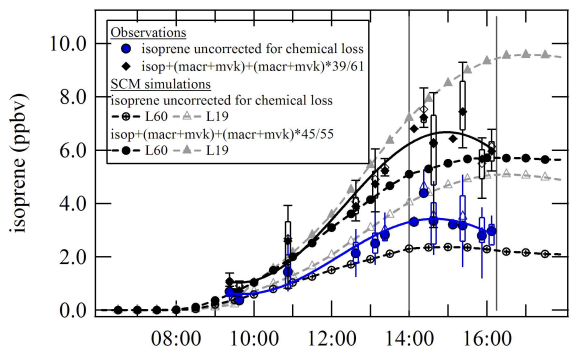

a)

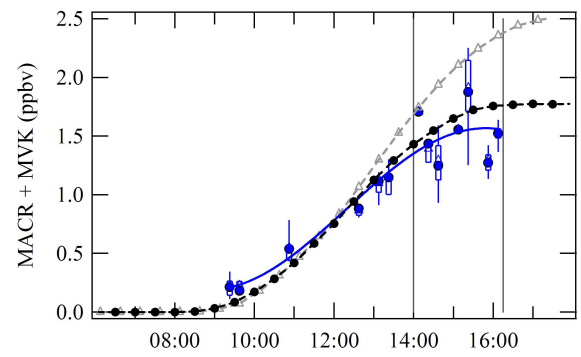

b)

Local Time
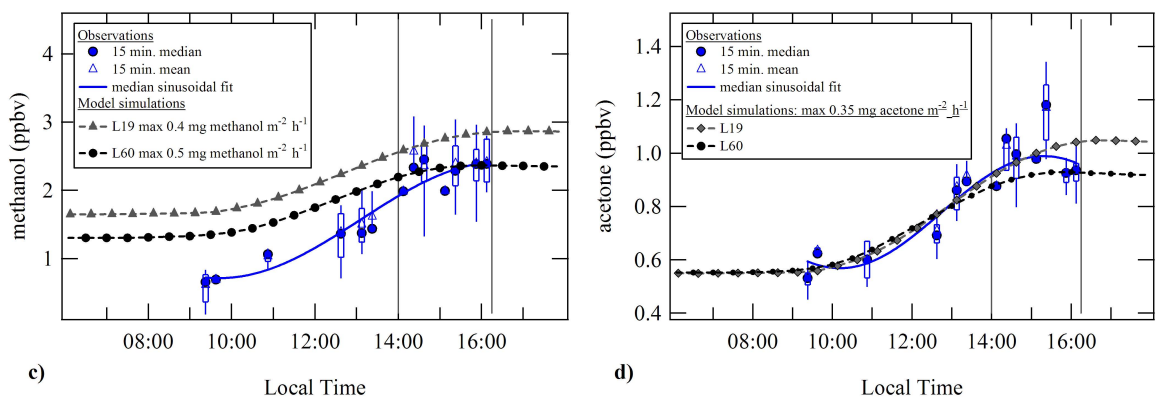

Fig. 8. Mixed layer diurnal cycles for isoprene and its oxidation products, methanol and acetone over the Guyana's rainforest (first day over land).

maximum height of $1280 \mathrm{~m}$ a.s.l.), sampling effectively occurred at various heights above surface. Therefore the height above ground has been explicitly considered (calculated with SRTM3 digital elevation model data) instead of the pressure altitude. Median values of the quarter hourly $5 \mathrm{p}-95 \mathrm{p}$ box and whisker plots have been fitted to both a 5 th order polynomial fit and a sinusoidal fit. Such fits have been also applied in combination with the CBL depth to infer surface fluxes from mixing ratio observations as discussed in Sect. 5.7. The green vertical lines indicate the time interval for which the vertical profiles were taken.

Airborne and ground-based observations of isoprene mixing ratios show a distinct diurnal cycle, being very low in the morning, reaching peak values around mid-afternoon, and decreasing towards the evening. Strong gradients in isoprene from the canopy source to the top of the mixed layer were the reason for the wide range of values measured at any given time in the diurnal plot. The ground-based measured values ( $25 \mathrm{p} /$ med. / 75 p / 95 p: 3.3 / 4.3 / 5.4 / 6.2 ppbv, 14:0016:15 LT) were higher than those taken in the mixed layer

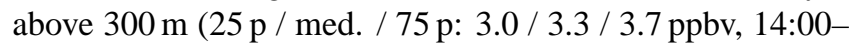
$16: 15 \mathrm{LT}$ ), indicating the role of turbulent exchange in diluting as well as the high reactivity of isoprene towards the oxidants $\mathrm{OH}$ and $\mathrm{O}_{3}$. K34 tower measurements near Manaus (July 2001, beginning of the dry season, LBA-CLAIRE-2001 campaign) by Kuhn et al. (2007) showed lower mean canopy level daytime mixing ratios of $3.4 \mathrm{ppbv}$ with a maximum of $6.6 \mathrm{ppbv}$ for isoprene. Higher mean noontime surface layer isoprene mixing ratios of $7.8 \pm 3.7 \mathrm{ppbv}$, with peak values up to $15 \mathrm{ppbv}$, were obtained during the TROFFEE campaign on the Z14 tower in September 2004 (end of the dry season). The observed mixed layer mixing ratios show a range between 0.6 and $6.7 \mathrm{ppbv}$ with a mean of $5.2 \mathrm{ppbv}$ (Karl et al., 2007). These results are comparable to, though slightly higher than the mixing ratios reported here.

Figure 8b shows that mixed layer MACR and MVK mixing ratios show less variability compared to isoprene. This is because they are formed aloft in the well-mixed boundary layer and have significantly longer chemical lifetimes. Their average summed median mixing ratio was $1.4 \mathrm{ppbv}$, ranging between $1.2-1.8 \mathrm{ppbv}(25 \mathrm{p}-75 \mathrm{p}$ ) and which is similar to the observations reported by Karl et al. (2007), $2.1 \mathrm{ppbv}$, and by Warneke et al. (2001), 2.5 ppbv, whereas observations by Kuhn et al. (2007) were substantially smaller ( $\sim 0.5 \mathrm{ppbv})$.

Figure 8 shows that both the L19 and L60 model simulations reproduced the mixed layer diurnal cycles of the BVOCs before 14:00 LT reasonably well and that afterwards, only L60 simulations are in reasonable agreement with the observations. This suggests that the discrepancy between the modelled and the observed BVOC mixing ratios was likely associated with a misrepresentation of turbulent and convective transport and cloud formation, also affecting surface emissions and photolysis. Furthermore, Fig. 9 shows that increasing the vertical resolution in the SCM from L19 to L60 resulted in an increase in simulated $\mathrm{OH}$. However, differences in simulated turbulent and convective mixing apparently do not adequately explain the discrepancy between the modelled and the measured $\mathrm{OH}$-concentrations. Measured $\mathrm{OH}$ data exhibited a much less pronounced diurnal variation in the mixed layer over the rainforest than in the model (see 


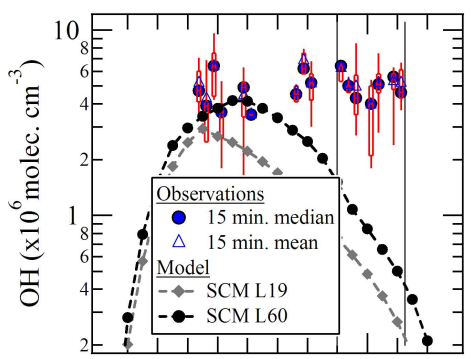

$10: 00 \quad 15: 00$

a)

Local Time

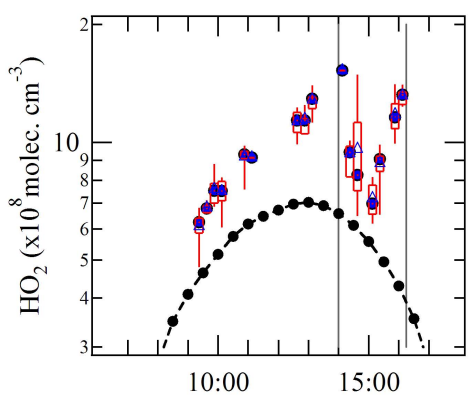

b)

Local Time

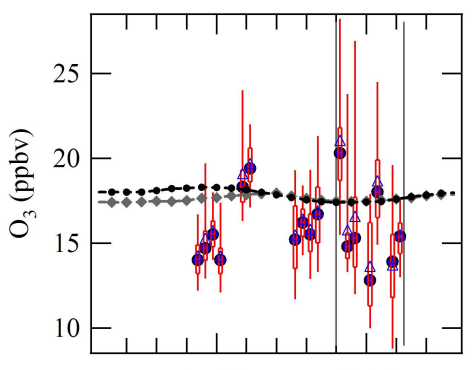

10:00 15:00

Local Time

Fig. 9. Measured and modelled diurnal cycles of $\mathrm{OH}, \mathrm{HO}_{2}$ and $\mathrm{O}_{3}$ above the rainforest for October 2005.

Fig. 9a). The best agreement is obtained between 09:00 and 09:30 LT when isoprene is still low and simulated $\mathrm{NO}_{\mathrm{x}}$ concentrations are relatively large. This reflects the release of $\mathrm{NO}_{\mathrm{x}}$, accumulated in the nocturnal inversion layer, out of the canopy into the mixed layer. Later in the day the discrepancy increases, pointing to a potential misrepresentation of the afternoon sources and/or sinks reactive tracers and $\mathrm{OH}$, e.g. $\mathrm{OH}$ and $\mathrm{HO}_{2}$-recycling involved in the isoprene oxidation mechanism (Butler et al., 2008; Lelieveld et al., 2008).

Canopy level observations of MACR+MVK (25 p / med. / 75 p: 5.0 / 6.4 / 8.0 ppbv, 14:00-17:00 LT) at Brownsberg were slightly higher but comparable to the average noontime mixing ratios of 2.3 ppbv reported by Kuhn et al. (2007) and 2.5 ppbv by Karl et al. (2007).

Figure $8 \mathrm{c}$ and $\mathrm{d}$ shows strong increases in both methanol and acetone in the mixed layer as a function of time of day. The observed morning mixing ratios for acetone and methanol are $\sim 0.6 \mathrm{ppbv}$. The diurnal increase in methanol is larger compared to that in acetone. Afternoon methanol mixing ratios increased to $2-3 \mathrm{ppbv}$ and those for acetone to $0.9-1.1 \mathrm{ppbv}$, and $0.18-0.20 \mathrm{ppbv}$ for acetonitrile.

In the absence of significant anthropogenic activity and low biomass burning influences, the observed increases in acetone and methanol must reflect direct biogenic emission from the rainforest and/or secondary production. The average simulated acetone mixing ratios, based on the compensation point approach with daytime emissions and night time deposition, agreed well with the measurements. Methanol mixing ratios were overestimated by the model by about 0.6 ppbv for the 3rd day of the SCM L60 simulation despite initialisation of SCM with the observed mixing ratio profiles over the ocean. This difference may be caused by the variation in the free troposperic methanol mixing ratios present in the advected air. Ganzeveld et al. (2008) showed that the model underestimated the mixing as well as the nocturnal deposition of all tracers discussed here; this issue is especially relevant for the evaluation of the observations further inland.

\subsection{Chemical and mixing time scales}

The photochemical age $t$, or the extent of chemical processing of isoprene in the encountered air masses will be used in the flux calculation (next section). An expression for this age can be derived by solving Eq. (1) for $t$, using the ratio of [product] to [precursor], based on the Reactions (R1, R2, $\mathrm{R} 3$ ) assuming pseudo first order reactions and a dominance of the $\mathrm{OH}$ sink:

$$
\begin{aligned}
& \begin{aligned}
\frac{\mathrm{MACR}+\mathrm{MVK}}{\mathrm{ISOP}} & =\left(\frac{\gamma_{\mathrm{MACR}} k_{1}}{\left(k_{2}-k_{1}\right)}\right)\left(1-e^{\left(\left(k_{2}-k_{1}\right)[\mathrm{OH}] t\right)}\right) \\
& +\left(\frac{\gamma_{\mathrm{MVK}} k_{1}}{k_{3}-k_{1}}\right)\left(1-e^{\left(\left(k_{1}-k_{3}\right)[\mathrm{OH}] t\right)}\right)
\end{aligned} \\
& \mathrm{ISOP}+\mathrm{OH} \stackrel{k_{1}=k_{\text {isop }, \mathrm{OH}}}{\longrightarrow} \gamma_{\mathrm{MACR}} \mathrm{MACR}+\gamma_{\mathrm{MVK}} \mathrm{MVK} \\
& \mathrm{MACR}+\mathrm{OH} \stackrel{k_{2}=k_{\mathrm{mar}, \mathrm{OH}}}{\longrightarrow} \text { products } \\
& \mathrm{MVK}+\mathrm{OH} \stackrel{k_{3}=k_{\mathrm{mvk}, \mathrm{OH}}}{\longrightarrow} \text { products }
\end{aligned}
$$

$\gamma_{\text {macr }}$ and $\gamma_{\mathrm{mvk}}$ are the $\mathrm{OH}$ oxidation yields for MACR and MVK respectively under low $\mathrm{NO}_{\mathrm{x}}$, the reaction rate constants were taken accordingly as $k_{\text {isop }, \mathrm{OH}}=2.7 \mathrm{E}-11 * \exp (390 / \mathrm{T}) ; k_{\text {macr }, \mathrm{OH}}=8 \mathrm{E}-12 * \exp (389 / \mathrm{T})$ and $k_{\mathrm{mvk}, \mathrm{OH}}=2.6 \mathrm{E}-12 * \exp (610 / \mathrm{T}$ ) (IUPAC, 2007b, a, c) and $[\mathrm{OH}]$ as measured over the rainforest.

The ratio of [MVK+MACR]/[isoprene] has been studied elsewhere e.g. (Biesenthal et al., 1998; Stroud et al., 2001; Apel et al., 2002) and has shown a $\mathrm{NO}_{\mathrm{x}}$ dependency. Here we compare the observed vertical profile (14:00-17:00 LT) and diurnal cycle to the model simulation for the surface and the mixed layer in Fig. 10a and b. The observed profile is comparable to the one obtained for the TROFFEE campaign by Karl et al. (2007). However, [MVK+MACR]/[isoprene] varied over a large range and an interpretation of this ratio is complicated since it depends on the history of the air mass (forest contact time), on vertical mixing and on chemistry (dominated by $\mathrm{OH}$ as $\mathrm{O}_{3}$ mixing ratios were low (10-20 ppbv)). 

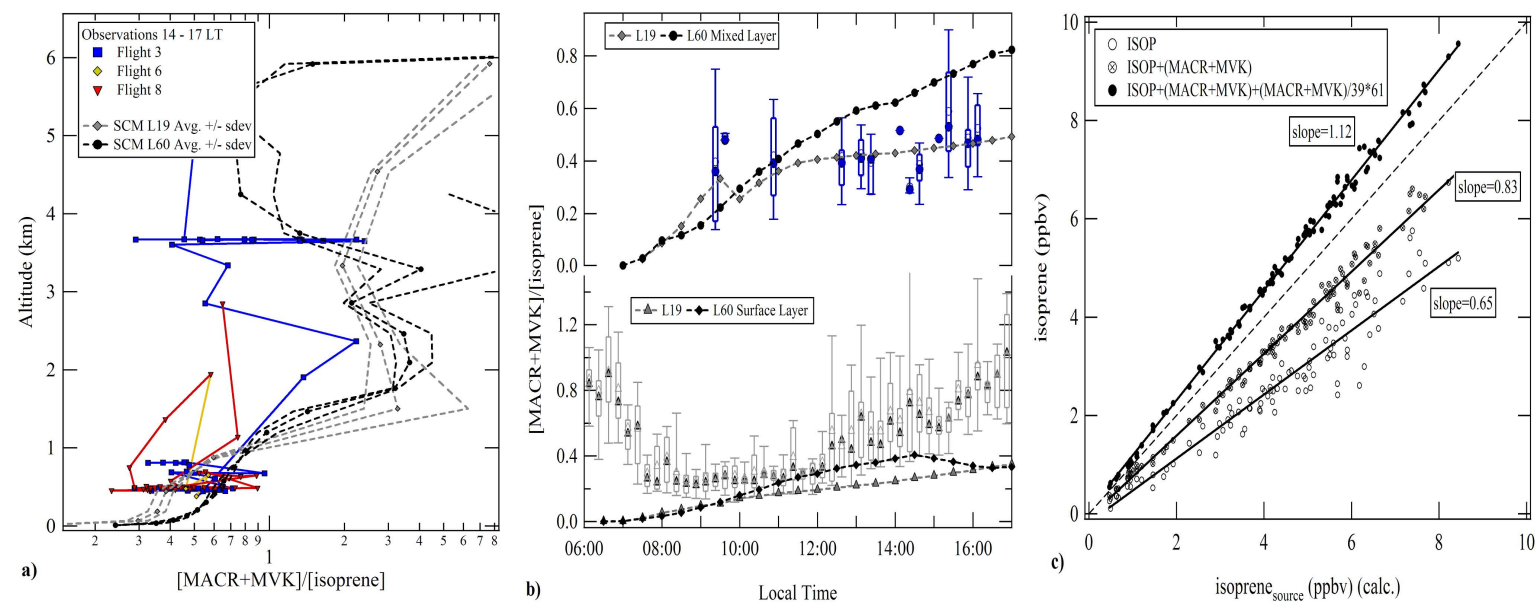

Fig. 10. Comparison of the measured to the modelled vertical (14:00-17:00 LT) and diurnal cycle of [MACR+MVK]/[isoprene] (first day over land). Comparison of compensation for chemical loss of isoprene (see text).

The $\mathrm{OH}$ concentrations measured during GABRIEL (Fig. 9) were on average of $5.0 \times 10^{6}$ molec. $\mathrm{cm}^{-3}$ in the mixed layer and $\sim 8.1 \times 10^{6}$ molec. $\mathrm{cm}^{-3}$ between 2 and $5 \mathrm{~km}$. These measured concentrations are substantially higher than the OH concentrations estimated by Karl et al. (2007) and Kuhn et al. (2007) in a convective boundary layer budget analysis. The observed $[\mathrm{MVK}+\mathrm{MACR}] /[$ isoprene] ratios above the CBL height were higher than those in the CBL reflecting low mixing ratios of isoprene and upward transport of oxidation products.

Surface layer data from Brownsberg revealed a diel pattern in the ratio $[\mathrm{MACR}+\mathrm{MVK}] /[$ isoprene] that drops at sunrise from $\sim 0.8$ to $\sim 0.3$ around 08:00 LT, then remains rather constant at $\sim 0.3$ until noon, followed by an increase until sunset (see Fig. 10b, lower panel). The drop in ratio in the morning hours could possibly reflect breakup of the nocturnal boundary layer and mixing in of residual layer air. However, observations of meteorological parameter to support this hypothesis were unfortunately not available. The model assumes an equilatitudinal transect (at $4.5^{\circ} \mathrm{N}$ ) exclusively above the ocean before sunrise and consequently the bottom panel of Fig. 10b shows an almost constantly increasing ratio between sunrise and sunset in the surface layer. In addition, the simulated [MACR+MVK]/[isoprene] ratio is lower for L19 than for L60 version but both are lower than observed, also reflecting the fact that the model calculates lower $\mathrm{OH}$ concentrations.

Differences in measured and modelled product-precursor ratio suggest a much shorter "measured" photochemical age of isoprene (19 and $27 \mathrm{~min}$ ) than the simulated age ( 0.5 to $\sim 2 \mathrm{~h}$ ). It should be noted that solving Eq. (1) for $t$ using high $\mathrm{NO}_{\mathrm{x}}$ rather than low $\mathrm{NO}_{\mathrm{x}}$ branching yields generally a $23 \%$ longer photochemical age.

For the GABRIEL boundary layer conditions, calculated atmospheric lifetimes for isoprene, MACR, and MVK with respect to both $\mathrm{OH}$ and $\mathrm{O}_{3}$ were on average $0.5,2$ and $2.75 \mathrm{~h}$, respectively. For acetone and methanol, we calculate atmospheric lifetimes of 2.5 and 13.5 days, respectively. Due to the misrepresentation of $\mathrm{OH}$ and the different mixing in the model, the actual atmospheric lifetime of isoprene is much shorter than simulated ( 1 to $3.5 \mathrm{~h}$ before 14:00 LT to $6 \mathrm{~h}$ and more afterwards.

In order to compare the mixing and chemistry timescales we estimate the convective timescale, i.e. the time scale for the air to circulate between the surface and the top of the mixed layer (large Eddy). For this we assume typical tropical meteorological parameters (as observed during the TROFFEE campaign in September 2004, T. Karl, personal communication, 2007) to estimate the timescale for convective mixing $\left(t^{*}\right)$ based on the convective velocity scale $\left(w^{*}\right)$ and the boundary layer height $\left(z_{i}\right)$. We used a maximum sensible heat flux $\sim 200 \mathrm{~W} \mathrm{~m}^{-2}$ (also simulated by the SCM) before noon declining to $\sim 100 \mathrm{~W} \mathrm{~m}^{-2}$ in the afternoon (due to cloud cover) and a surface temperature diurnal cycle as observed at Brownsberg $\left(24-26^{\circ} \mathrm{C}\right)$. In this way we obtain a maximum convective velocity scale of $2 \mathrm{~m} / \mathrm{s}$ which is in the range of the convective velocity scale obtained for the TROFFEE campaign. The result is an inferred convective time scale between $8 \mathrm{~min}$ in the morning to $16 \mathrm{~min}$ in the afternoon which is substantially shorter than the chemical time scale and the photochemical age calculated above.

\subsection{Flux calculations}

The emission surface flux was derived from the airborne measurements over the rainforest by the CBL budgeting approach based on Eq. (2). This CBL budgeting approach assumes a quasi-stationary steady state for the vertical profiles, and as a result vertical linear flux profiles are obtained. It uses the natural integrating properties of the well-mixed atmospheric boundary layer, allowing average surface fluxes to be obtained over relatively larger regions. 
Table 1. Maximum median observed mixed layer and surface layer emission fluxes for isoprene methanol and acetone in a CBL height up to $\sim 1450 \mathrm{~m}$.

\begin{tabular}{lll}
\hline$\left(\mathrm{mg} \mathrm{m}^{-2} \mathrm{~h}^{-1}\right)$ & $F_{s}-F_{e}$ & $F_{s}^{\text {Brownsberg }}$ \\
\hline isoprene & 2.5 & 2.2 \\
isoprene+MACR+MVK & 3.7 & 3.7 \\
isoprene+(MACR+MVK)+ & & \\
(MACR+MVK)/39*61 & 5.7 & 6.3 \\
methanol & 0.50 & 0.36 \\
acetone & 0.35 & 0.36 \\
\hline
\end{tabular}

Vilà-Guerau de Arellano et al. (2009) discusses this method and addresses the quantitative importance of each of the four terms. In short, the surface emission flux $\left(F_{S}\right)$ is inferred from observations using:

$F_{S}=h\left[\frac{\partial\langle S\rangle}{\partial t}-R+\left(U \frac{\partial\langle S\rangle}{\partial x}+V \frac{\partial\langle S\rangle}{\partial y}\right)\right]+F_{e}$

This method is time dependent reflecting the role of chemistry and the mixing (vertical transport). We assume that the tendency term $\partial<\mathrm{S}>/ \partial t$ (the change in the concentration of a BVOC as function of time, taken from the inferred diurnal profile) within a boundary layer volume ( $h$, determined in Sect. 5.1), results in the net flux of the tracer. Although this term was mainly important in the early morning, the contribution for chemical loss term $(R)$ was imperative during the day. The longer the atmospheric lifetime, the smaller the contribution chemical losses term will be and for inert species, concentration changes with time are only due to the surface emission/deposition and entrainment of free troposphere air masses while neglecting the advection term.

As a consistency check, $\mathrm{CO}_{2}$ data measured on board of the Learjet during GABRIEL to determine the daytime $\mathrm{CO}_{2}$ uptake assuming a boundary layer height up to $\sim 1450 \mathrm{~m}$. A median value of $2.73 \mathrm{~g} \mathrm{CO}_{2} \mathrm{~m}^{-2} \mathrm{~h}^{-1}$ and an average of $4 \mathrm{~g} \mathrm{CO}_{2} \mathrm{~m}^{-2} \mathrm{~h}^{-1}$ (sinusoidal fit through $15 \mathrm{~min}$ binned data between 300 and $800 \mathrm{~m}$ over the rainforest) are found to be in reasonable agreement with the daytime $\mathrm{CO}_{2}$ uptake measured under high irradiance state of 2.53$3.01 \mathrm{~g} \mathrm{CO}_{2} \mathrm{~m}^{-2} \mathrm{~h}^{-1}$ over an old-growth tropical forest in Para, Brazil from July 2000 to July 2001 using an eddy covariance technique by Goulden et al. (2004).

For chemical reactive species like isoprene the reactivity term $(R)$ needs to be taken into account. We propose here two different ways to calculate $R$ :

1) In case $\mathrm{OH}$ has not been measured, we estimate isoprene at the canopy level by summing up the precursor and product concentrations as follows

$$
R_{1}=\frac{\partial\langle\text { isoprene }+(\mathrm{MACR}+\mathrm{MVK})+(\mathrm{MACR}+\mathrm{MVK}) / 39 * 61\rangle}{\partial t}
$$

based on the low $\mathrm{NO}_{\mathrm{x}}$ oxidation yield. Note that although formaldehyde has been measured, it cannot exclusively be attributed to the oxidation of isoprene.

2) In case that $\mathrm{OH}$ has been measured, isoprene mixing ratios can be inferred according to:

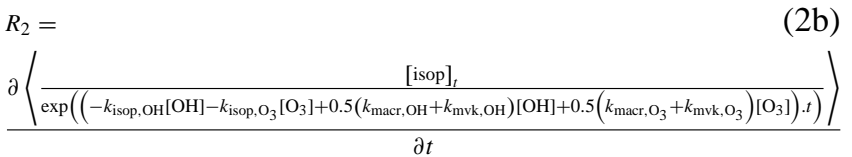

in which $t$ corresponds to the photochemical age as discussed earlier.

In this way, we can study the sensitivity of the surface emission to different chemical mechanisms. Figure 10c shows the isoprene mixing ratios calculated using the two reaction terms $R_{1}$ and $R_{2}$. From the linear slope of 1.12 we conclude that both methods provide comparable estimates of isoprene at the canopy level.

For the entrainment flux we calculate first a diurnal profile of $F_{s}-F_{e}$ before taking $F_{e}$ into account (see below). A maximum value of $F_{s}-F_{e}$ of $5.7 \mathrm{mg}$ isoprene $\mathrm{m}^{-2} \mathrm{~h}^{-1}$ (method 1 , see Fig. 11) and $5.2 \mathrm{mg}$ isoprene $\mathrm{m}^{-2} \mathrm{~h}^{-1}(\operatorname{method} 2)$ for a CBL up to $1450 \mathrm{~m}$ was obtained.

Ideally, to examine oxidation one should follow the same air mass as it traverses the landscape as was done by the SCM. Practically, only relatively short (few hours), discontinuous periods (spread over 14 days) of airborne measurements were available for analysis. The rather constant meteorological boundary conditions during GABRIEL 2005 support the use of this method. By limiting ourselves to the first day over land we have eliminated the influence of residual layer air which complicates interpretation of daytime BVOC exchanges (Ganzeveld et al., 2008). We therefore neglect the advection term (involving the partial derivative towards $x$ and $y$ ) on the right hand side of Eq. (2) as we inherently assume that the emissions occur into clean air advected from the ocean during the previous night. Empirically, we use sinusoidal and 5th polynomial fits through the median values of 15 min binned concentrations presented in Fig. 8 to calculate the mixed layer fluxes for the first day over land. Both fits have been of equal merit for interpolation.

Methods to determine the importance of entrainment are often: (i) based on a distinct concentration jump $(\Delta S)$ across the CBL like e.g. $F_{e}=-w_{\text {entr }}\left(C_{\mathrm{CBL}}-C_{\mathrm{FT}}\right)$ with $w_{\text {entr }}$ being the boundary layer growth on time as used in e.g. Goulden et al. (2004) or (ii) related to the overshoot and exchange of heat, moisture and compounds driven by the thermals $F_{e}=K_{e} d C / d z$, where the exchange coefficient $K_{e}$ is proportional to the convective velocity scaling and inversely proportional to $d T / d z$. It can be questioned if these methods, which are strictly speaking valid under clear sky conditions, are applicable to clouded boundary layers with a less pronounced concentration jump. This discussion has been further pursued in Vilà-Guerau de Arellano et al. (2009). 

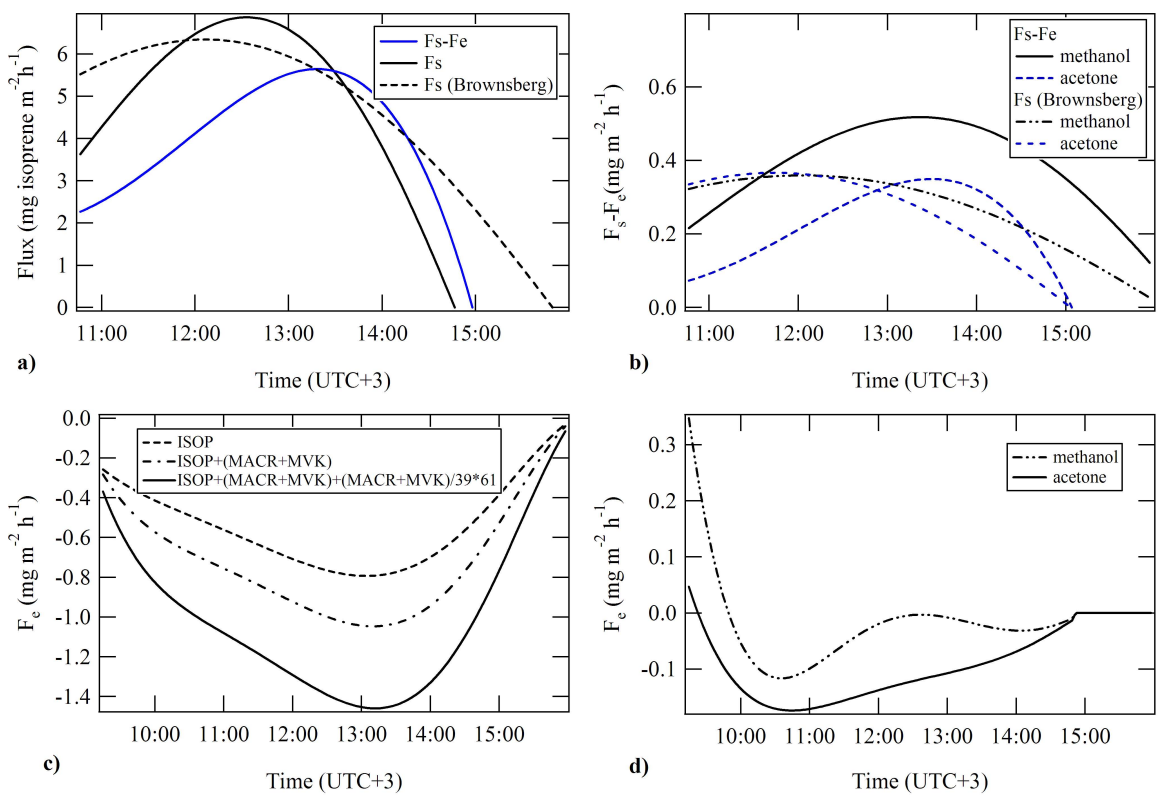

Fig. 11. (a and b) Comparison of the mixed layer median fluxes for isoprene (after correction for chemical loss), methanol and acetone to their surface layer fluxes obtained for Brownsberg. (c and d) Estimated entrainment fluxes based on the concentration jump method.

Overshoots beyond the clear sky boundary layer due to shallow cumuli clouds (as indicated in Fig. 4b) are important, but the transport level is not uniform over the entire domain due to partial cloud cover.

Based on the concentration jump method we estimate a maximum detrainment flux $\left(F_{e}\right)$ of $1.4 \mathrm{mg}$ isoprene $\mathrm{m}^{-2} \mathrm{~h}^{-1}$ around 13:20LT for a boundary layer that grows to $1450 \mathrm{~m}$. Consequently, we obtain a surface flux $\left(F_{s}\right)$ of $6.9 \mathrm{mg}$ isoprene $\mathrm{m}^{-2} \mathrm{~h}^{-1}$. The detrainment flux for isoprene is on the order of $45 \%$ down to $25 \%$ of the surface flux between 10:00 and 12:00 LT. This is in good agreement with the findings of e.g. Fedorovich (1995) and Spirig et al. (2004) for a tropical rainforest site near Manaus.

To estimate the surface flux for Brownsberg, we assume the same CBL evolution as used for the airborne data. Since $\mathrm{OH}$ concentrations were not measured within the canopy, we compensate for chemical loss by using $(\mathrm{ISOP}+\mathrm{MACR}+\mathrm{MVK}+(\mathrm{MACR}+\mathrm{MVK}) * 61 / 39)$. A value for $F_{s}-F_{e}$ of $6.3 \mathrm{mg}$ isoprene $\mathrm{m}^{-2} \mathrm{~h}^{-1}$ has been obtained which is agreement with our regional surface flux derived from the aircraft data

In Table 2, the GABRIEL results are compared with previous tropical forest emission studies. We conclude that the isoprene fluxes obtained here are higher than e.g. mean REA-measured isoprene fluxes of $2.5 \mathrm{mg}$ isoprene $\mathrm{m}^{-2} \mathrm{~h}^{-1}$, which were measured under cloudy conditions in Costa Rica in October 1999 by Geron et al. (2002). Similarly, Karl et al. (2004) observed on average 1.72 (max $2.5 \mathrm{mg}$ isoprene $\mathrm{m}^{-2} \mathrm{~h}^{-1}$ ) for a drought-stressed Costa Rican ecosystem in April-May, 2003. These results suggest that tropical rainforest of Costa Rica seems generally to emit less isoprene compared to the Amazon and the Guyanas rainforests.

Karl et al. (2007) described how an average eddy covariance surface flux of $8.3 \pm 3.1 \mathrm{mg}$ isoprene $\mathrm{m}^{-2} \mathrm{~h}^{-1}$ or an average mixed layer gradient surface flux of $12.1 \pm 4.0 \mathrm{mg}$ isoprene $\mathrm{m}^{-2} \mathrm{~h}^{-1}$ was obtained near to the centre of the Amazon (Manaus). These measurements have also been conducted under partially cloudy sky for a boundary layer which was defined to be $\sim 1200 \mathrm{~m}$ deep, corresponding to the bottom of the developing cloud layer. This is different to the definition used here, as discussed earlier.

Kuhn et al. (2007) reported a mean midday isoprene flux of $6.2 \mathrm{mg}$ isoprene $\mathrm{m}^{-2} \mathrm{~h}^{-1}$ using the mixed layer gradient method for a mixed layer depth of $\sim 1100 \mathrm{~m}$ near Manaus in July 2001. They state that this flux was on average about a factor two higher than the fluxes derived from tower-based measurements reported in the same study.

Karl et al. (2007) and Kuhn et al. (2007) used the mixed box technique to estimate the $\mathrm{OH}$ concentration over the tropical rainforest (assuming an entrainment term). Given by:

$F_{s}-F_{e}=\frac{C}{\tau} z_{i}=\left(k_{\text {isop }, \mathrm{OH}}[\mathrm{OH}]_{t}+k_{\text {isop }, \mathrm{O}_{3}}\left[\mathrm{O}_{3}\right]_{t}\right) C_{\text {average } t} z_{i}$

in which Caverage is the average PBL concentration, $z_{i}$ is the height of the PBL.

In contrast, we have measured all parameters on the right hand side of Eq. (3) (including $\mathrm{OH}$ ). We obtain values for $F_{s}-F_{e}$ that range, for the well mixed afternoon conditions, between 16 and $25 \mathrm{mg}$ isoprene $\mathrm{m}^{-2} \mathrm{~h}^{-1}$ (25 p-75 p) 
Table 2. Oceanic vertical profiles for methanol, acetone and acetonitrile used for SCM-model initialisation.

\begin{tabular}{|c|c|c|c|}
\hline Flux $\left(\mathrm{mg} \mathrm{m}^{-2} \mathrm{~h}^{-1}\right)$ & \multicolumn{2}{|l|}{ isoprene } & Location, year, (season) \\
\hline Karl et al., 2007 & \multicolumn{2}{|c|}{ Avg: $7.8 \pm 2.3$} & Manaus \\
\hline EC, tower \& airborne, PTR-MS & \multicolumn{2}{|c|}{ Max: $12.1 \pm 4.0$} & September, 2004 (dry) \\
\hline Karl et al., 2004 & \multirow{2}{*}{\multicolumn{2}{|c|}{$\begin{array}{l}\text { Avg: } 1.72 \\
\text { Max: } 2.50\end{array}$}} & Heredia, Costa Rica \\
\hline DEC,tower, PTR-MS & & & April \& May, 2003 (dry) \\
\hline Geron et al., 2002 & \multirow{2}{*}{\multicolumn{2}{|c|}{$\begin{array}{l}\text { Avg: } 2.50 \\
\text { Max: } \sim 11\end{array}$}} & Heredia, Costa Rica \\
\hline REA, cartridges, GC-FID & & & October, 1999 (dry) \\
\hline $\begin{array}{l}\text { Kuhn et al., } 2007 \\
\text { REA,tower, cartridges, CGMS }\end{array}$ & \multicolumn{2}{|l|}{ Avg: 2.36} & $\begin{array}{l}\text { Manaus, Brazil, } \\
\text { July, } 2001 \text { (dry) }\end{array}$ \\
\hline $\begin{array}{l}\text { Rinne et al., } 2002 \\
\text { DEA,tower, cartridges, FIS }\end{array}$ & \multicolumn{2}{|l|}{ Max: 2.40 } & $\begin{array}{l}\text { Tapajós, Brazil } \\
\text { July, } 2000 \text { (end of wet) }\end{array}$ \\
\hline $\begin{array}{l}\text { Greenberg et al., 2004a } \\
\text { Tethered balloon, cartridges, CGMS }\end{array}$ & \multicolumn{2}{|l|}{ Max: $2.2^{*}$} & $\begin{array}{l}\text { Tapajós, Brazil } \\
\text { February, } 2000 \text { (wet) }\end{array}$ \\
\hline $\begin{array}{l}\text { Greenberg et al., 2004a } \\
\text { Tethered balloon, cartridges, CGMS }\end{array}$ & \multicolumn{2}{|l|}{ Max: $5.3 *$} & $\begin{array}{l}\text { Balbina, Brazil } \\
\text { March, } 1998 \text { (wet) }\end{array}$ \\
\hline $\begin{array}{l}\text { Greenberg et al., 2004a } \\
\text { Tethered balloon, cartridges, CGMS }\end{array}$ & \multicolumn{2}{|l|}{ Max: $9.8^{*}$} & $\begin{array}{l}\text { Rondônia, Brazil } \\
\text { February, } 1999 \text { (wet) }\end{array}$ \\
\hline \multirow[t]{2}{*}{$\begin{array}{l}\text { This study } \\
\text { airborne }\end{array}$} & \multicolumn{2}{|c|}{ Median: 6.9} & $\begin{array}{l}\text { French Guyana, Suriname } \\
\text { October } 2005 \text { (dry) }\end{array}$ \\
\hline & methanol & acetone & \\
\hline Karl et al., 2004 & Avg: 0.13 & Avg: 0.09 & Heredia, Costa Rica \\
\hline DEC,tower, PTR-MS & Max: 0.50 & Max: 0.36 & April \& May 2003 \\
\hline $\begin{array}{l}\text { Geron et al., } 2002 \\
\text { REA, cartidges, GC-FID }\end{array}$ & Avg: 1.41 & Avg: 2.25 & $\begin{array}{l}\text { Heredia, Costa Rica } \\
\text { October, } 1999\end{array}$ \\
\hline $\begin{array}{l}\text { This study } \\
\text { airborne }\end{array}$ & Med: 0.50 & Med:0.36 & $\begin{array}{l}\text { French Guyana, Suriname } \\
\text { October } 2005 \text { (dry) }\end{array}$ \\
\hline
\end{tabular}

* estimated from a box model by Guenther et al. (1999).

and a median of around $20 \mathrm{mg}$ isoprene $\mathrm{m}^{-2} \mathrm{~h}^{-1}$ for this region. Such flux values are much higher than we have obtained following the mixed layer budget approach and much higher than observed by both studies mentioned. Furthermore, the $\mathrm{OH}$-concentrations deduced over the rainforest by the aforementioned studies $\left(1.3 \pm 0.5 \times 10^{6}\right.$ molecules $\mathrm{cm}^{-3}$ and $2.5 \pm 1.5 \times 10^{6}$ molecules $\mathrm{cm}^{-3}$, respectively) are substantially lower than measured during GABRIEL (on average $\sim 5 \times 10^{6}$ molecules $\mathrm{OH} \mathrm{cm}{ }^{-3}$ ).

For the L19 and L60 SCM simulations, after compensation for chemical loss (by the sum of parent and product concentrations), we have calculated mixed layer maximum values for $F_{s}-F_{e}$ of 6.0 and $4.6 \mathrm{mg}$ isoprene $\mathrm{m}^{-2} \mathrm{~h}^{-1}$ respectively at 12:00 and 13:00, each with respect to their own simulated boundary layer evolution.

Due to the different $\mathrm{CBL}$ growth rates in each model version, entrainment maximum detrainment fluxes were calculated for conserved isoprene of 0.70 and $0.54 \mathrm{mg}$ isoprene $\mathrm{m}^{-2} \mathrm{~h}^{-1}$ for the L19 and L60 version respectively following the concentration jump method. In the
L60 version this maximum occurs around 10:00 whereas in the L19 version the maximum detrainment occurs at 12:00 which matches better the temporal variance of the observations.

The maximum surface layer fluxes of 6.6 and $6.1 \mathrm{mg}$ isoprene $\mathrm{m}^{-2} \mathrm{~h}^{-1}$ calculated for the L19 and L60 version, respectively, reflect the result from a simulated isoprene emission flux that has been scaled down by a factor 2 to arrive at daytime peak fluxes which are in agreement with the "observed" emission flux. Reducing the isoprene emission flux in the SCM does lead to higher $\mathrm{OH}$ concentrations, however, reducing the isoprene flux such that modelled and measured $\mathrm{OH}$-concentrations match, makes the isoprene mixing ratios then fall well below the measured values.

The CBL budgeting approach applied here inherently rejects outliers by using median values over distinct time spans (here $15 \mathrm{~min}$ ) but remains sensitive to changes in concentrations e.g. due to biomass burning plumes. Such events have not been considered in the methanol and acetone flux 
calculation and this has resulted in maximum mixed layer fluxes $\left(F_{s}-F_{e}\right)$ of, $0.50 \mathrm{mg}$ methanol $\mathrm{m}^{-2} \mathrm{~h}^{-1}$ and a maximum mixed layer flux of $0.35 \mathrm{mg}$ acetone $\mathrm{m}^{-2} \mathrm{~h}^{-1}$ as shown in Fig. 11 and summarised in Table 1. Estimating the entrainment flux for methanol is more complicated as the concentration difference between the mixed layer and the free troposphere was less pronounced than it was as for acetone. We note in particular possible contributions to acetone from terpene oxidation ( $\alpha$-pinene oxidation yield of $15 \%$ in absence of NO, Nozière et al., 1999) and methanol may be formed in the mixed layer as secondary products from the isoprene oxidation under low $\mathrm{NO}_{\mathrm{x}}$ (e.g. from the photolysis of glycolaldehyde, lifetime against $\mathrm{OH}$ of $6 \mathrm{~h}$ ), as well as from the self-reaction of alkyl peroxy radicals.

The GABRIEL data show entrainment in the early morning $(<10: 00 \mathrm{LT})$ for acetone and methanol, however, its importance could not be quantified. Acetone shows a detrainment flux profile with maximum of $0.17 \mathrm{mg}$ acetone $\mathrm{m}^{-2} \mathrm{~h}^{-1}$ between 10:00 and 11:00 LT. However, due to less significant concentration differences across the CBL the profile for methanol, a detrainment flux of $0.11 \mathrm{mg}$ methanol $\mathrm{m}^{-2} \mathrm{~h}^{-1}$ was obtained.

Since the surface diurnal cycles in methanol and acetone mixing ratios were rather similar, the fluxes were considered to be predominantly due to emissions from plants with only a relatively small fraction of these fluxes from decay (Warneke et al., 1999 and Martius et al., 2004). In the absence of $\mathrm{CO}$ measurements, only acetonitrile and acetaldehyde mixing ratios have been used to filter the Brownsberg data for eventual biomass burning influences. For both methanol and acetone, we obtain maximum median surface fluxes of $0.36 \mathrm{mg} \mathrm{m}^{-2} \mathrm{~h}^{-1}$, without correction for en/detrainment. These fluxes are comparable to the maximum surface layer fluxes of $0.36 \mathrm{mg}$ acetone $\mathrm{m}^{-2} \mathrm{~h}^{-1}$ and $0.5 \mathrm{mg}$ methanol $\mathrm{m}^{-2} \mathrm{~h}^{-1}$ reported by Karl et al. (2004) and higher than the average flux of $0.09 \mathrm{mg}$ acetone $\mathrm{m}^{-2} \mathrm{~h}^{-1}$ and $0.13 \mathrm{mg}$ methanol $\mathrm{m}^{-2} \mathrm{~h}^{-1}$ observed during these 3 weeks of disjunct eddy covariance measurements in Costa Rica. Values are nevertheless not as high as the mean REA fluxes of $2.25 \mathrm{mg}$ acetone $\mathrm{m}^{-2} \mathrm{~h}^{-1}$ reported by Geron et al. (2002) for October 1999.

Very low fluxes for species like acetone and methanol are obtained by use of Eq. (3), due to their long atmospheric lifetimes even though the observed mixing ratios are not substantially low.

In an alternative approach the fluxes of acetone and methanol were also estimated from their longitudinal concentration gradient in the boundary layer as function of the time over land (TOL). This gradient of relatively unreactive species builds up as the emissions accumulate in the air traversing the rainforest. TOL has been calculated along the back trajectories of the air parcels as discussed by Gebhardt et al. (2008). In contrast to the halogenated compounds, methanol and acetone do express a diurnal cycle. By interpreting the observations in a Lagrangian sense, i.e. with increasing TOL $(\max 14 \mathrm{~h}=$ sunset to sunrise), time of the day and consequent to the CBL height, fluxes can be determined. In this admittedly cruder approach, as less data points remain after filtering, the obtained mixed layer fluxes are $\sim 0.42 \pm 0.05 \mathrm{mg}$ methanol $\mathrm{m}^{-2} \mathrm{~h}^{-1}$ and $\sim 0.28 \pm 0.04 \mathrm{mg}$ acetone $\mathrm{m}^{-2} \mathrm{~h}^{-1}$ and are thereby comparable but slightly lower than obtained previously. The errors taken into account for the Orthogonal Distance Regression are the total measurement uncertainty on the PTR-MS measurements and an uncertainty of $20 \%$ on the time over land. Interestingly, this method also indicates a mixed layer methanol flux which is higher than observed for the groundbased measurements.

\section{Conclusions}

The presented analyses of airborne and ground-based observations of BVOC mixing ratios, complemented by the simulated tropical forest chemistry in a single column chemistry and climate model, in combination with $\mathrm{OH}$ measurements, have permitted an assessment of the chemistry occurring over the tropical rainforest. Empirically derived isoprene fluxes are significantly smaller (circa factor 2) than those predicted by the implementation of MEGAN in the SCM. However, it has been shown that even if such a "state of the art model" is adjusted to emit isoprene at the empirically determined rates, isoprene and $\mathrm{OH}$ radical levels cannot be accurately simulated. This is in spite of the fact that there is reasonable agreement between modelled and measured boundary layer meteorological parameters. The measured $\mathrm{OH}$-concentrations above the tropical rainforest were always higher than currently modelled. This suggests that for this region both the isoprene emission flux and the subsequent photochemistry are not well simulated by the SCM model version applied here.

The campaign average mixed layer depth was successfully extracted from the occurrences of potential temperature inversions. The depth rose from $\sim 500 \mathrm{~m}$ in the morning (09:00) to $\sim 1450 \mathrm{~m}$ in the afternoon. The SCM reproduces the main characteristics and evolution of the observed CBL. It has been shown that the deeper transport through clouds also affects the distribution of reactive tracers like isoprene and accordingly of MACR+MVK to higher altitudes. Methanol and acetone mixing ratio vertical profiles are less steep but suggest mixing throughout a higher vertical domain. The importance of deeper transport through clouds was directly related to the cloud cover which increased over the course of a day.

The mixed layer diurnal cycle of isoprene showed low mixing ratios (ca. $0.5 \mathrm{ppbv}$ ) in the morning increasing to about $3.5 \mathrm{ppbv}$ in the afternoon. Mixing ratios measured from the aircraft were significantly lower than those measured at the surface since the transported air has been impacted by chemical oxidation and by mixing in of air from above. 
It was shown that the mixed layer isoprene diurnal cycles can be used to empirically determine the emission flux using the CBL budgeting approach provided that other influences such as boundary layer dynamics and chemistry are taken into account. A maximum median mixed layer flux $F_{s}-F_{e}$ of $5.7 \mathrm{mg} \mathrm{m}^{-2} \mathrm{~h}^{-1}$ for isoprene was corrected for detrainment into a surface flux of $6.9 \mathrm{mg}$ isoprene $\mathrm{m}^{-2} \mathrm{~h}^{-1}$, which is in good agreement with surface observations at Brownsberg. Based on this, the Guyana's rainforest emits 93.4 $\mathrm{mg}$ isoprene $\mathrm{m}^{-2} \mathrm{day}^{-1}$ for the dry season ( $\sim 6$ month per year). To estimate the annual emission, we assume a surface cover of 11 million $\mathrm{km}^{2}$ for this tropical rainforest ecosystem (Mayaux et al. (1998) and a 5 times higher isoprene emission rate for the dry season than for the wet season (based on the results from the TROFFEE and the AMAZE campaigns around Manaus). We estimate the annual isoprene emission from the tropical rainforest to be $232 \mathrm{Tg} \mathrm{C} \mathrm{yr}^{-1}$. However, model simulations (Guenther et al., 2006) and previous measurements show that the isoprene emission rate increases further inland and therefore the total amount of carbon from the tropical rainforest will in all probability be higher. Analogously, daily maximum median surface layer fluxes of $0.5 \mathrm{mg}$ methanol $\mathrm{m}^{-2} \mathrm{~h}^{-1}$ and $0.35 \mathrm{mg}$ acetone $\mathrm{m}^{-2} \mathrm{~h}^{-1}$, respectively correspond to annual

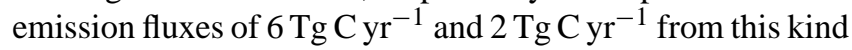
of tropical rainforest.

Higher resolved boundary layer schemes in the SCM (and other state-of-the art atmospheric chemistry and transport models) compared to default resolution of 5 layers in the $\mathrm{CBL}$ are required in order more realistically simulate the vertical distribution of water and energy, BVOCs and other tracers over the course of a day. A vertical resolution of 13 layers within the boundary layer effectively reduced boundary mixing ratios by circa $30 \%$ and increased the $\mathrm{OH}$ concentration by almost 50\% between 09:00 and 16:00 LT. As the SCM's default resolution is commonly used in global chemistrytransport models, such increase could affect the prediction of the oxidation capacity of the atmosphere above tropical rainforests.

Additional regional scale observations of BVOC concentrations and fluxes are needed over tropical continents in combination with high resolution boundary layer meteorological measurements to better constrain the budget of BVOCs emitted by the different tropical ecosystems. Furthermore in-depth investigation of the underlying low $\mathrm{NO}_{\mathrm{x}}$, organic oxidation chemistry in the remote troposphere is needed to improve current atmospheric models.

Acknowledgements. We would like to acknowledge the whole GABRIEL team for their great efforts and enthusiasm. Special gratitude goes to the pilots and the technicians of the GFD (Gesellschaft für Flugzieldarstellung, Hohn, Germany). We wish to thank Enviscope $\mathrm{GmbH}$ (Frankfurt, Germany) for the flight data and technical support, the Royal Meteorological Institute De Bilt, in the Netherlands and Suriname Meteorological Service for meteorological data and simulations.
We also thank Christian Gurk, Uwe Parchatka and Horst Fischer (for $\mathrm{H}_{2} \mathrm{O}, \mathrm{CO}_{2}, \mathrm{CO}, \mathrm{O}_{3}, \mathrm{NO}$ and TOL). We thank Thomas Karl and Alex Guenther for helpful discussions about the mixed box technique and Geoff Harris for helpful discussions at the outset.

The service charges for this open access publication have been covered by the Max Planck Society.

Edited by: R. Cohen

\section{References}

Apel, E. C., Riemer, D. D., Hills, A., Baugh, W., Orlando, J., Faloona, I., Tan, D., Brune, W., Lamb, B., Westberg, H., Carroll, M. A., Thornberry, T., and Geron, C. D.: Measurement and interpretation of isoprene fluxes and isoprene, methacrolein, and methyl vinyl ketone mixing ratios at the PROPHET site during the 1998 Intensive, J. Geophys. Res., 107, 4034, doi:10.1029/2000JD000225, 2002.

Benkelberg, H.-J., Böge, O., Seuwen, R., and Warneck, P.: Product distributions from the $\mathrm{OH}$ radical-induced oxidation of but1-ene, methyl-substituted but-1-enes and isoprene in $\mathrm{NO}_{\mathrm{x}}$-free air, Phys. Chem. Chem. Phys., 2, 4029-4039, 2000.

Biesenthal, T. A., Bottenheim, J. W., Shepson, P. B., Li, S. M., and Brickell, P. C.: The chemistry of biogenic hydrocarbons at a rural site in eastern Canada, J. Geophys. Res.-Atmos., 103, 2548725498, 1998.

Bolton, D.: Computation of equivalent potential temperature, Mon. Weather Rev., 108, 1046-1053, 1980.

Butler, T. M., Taraborrelli, D., Brühl, C., Fischer, H., Harder, H., Martinez, M., Williams, J., Lawrence, M. G., and Lelieveld, J.: Improved simulation of isoprene oxidation chemistry with the ECHAM5/MESSy chemistry-climate model: lessons from the GABRIEL airborne field campaign, Atmos. Chem. Phys., 8, 4529-4546, 2008, http://www.atmos-chem-phys.net/8/4529/2008/.

Carter, W. P. L. and Atkinson, R.: Development and evaluation of a detailed mechanism for the atmospheric reactions of isoprene and $\mathrm{NO}_{\mathrm{x}}$, Int. J. Chem. Kinet., 28, 497-530, 1996.

Colomb, A., Williams, J., Crowley, J., Gros, V., Hofmann, R., Salisbury, G., Klüpfel, T., Kormann, R., Stickler, A., Forster, C., and Lelieveld, J.: Airborne measurements of trace organic species in the upper troposphere over Europe: the impact of deep convection, Environ. Chem., 3, 244-259, 2006.

de Gouw, J., Warneke, C., Karl, T., Eerdekens, G., van der Veen, C., and Fall, R.: Sensitivity and specificity of atmospheric trace gas detection by proton-transfer-reaction mass spectrometry, Int. J. Mass Spectrom., 223-224, 365-382, 2003a.

de Gouw, J. and Warneke, C.: Measurements of volatile organic compounds in the earths atmosphere using proton-transferreaction mass spectrometry, Mass Spectrom. Rev., 26, 223-257, 2007.

de Gouw, J. A., Warneke, C., Holzinger, R., Klüpfel, T., and Williams, J.: Inter-comparison between airborne measurements of methanol, acetonitrile and acetone using two different configured PTR-MS instruments, Int. J. of Mass Spectrom., 239, 129137, 2003b.

Eerdekens, G.: Investigation of the possible interferences in the PTR-MS measurements of ambient air by use of GC-PTR-MS. 
Development of an all-Teflon injection system for GC-PTR-MS., Master of Chemistry, Institute for Marine and Atmospheric research Utrecht, Faculty of Physics and Astronomy, University of Utrecht, Utrecht, 2001.

Ehhalt, D. and Prather, M.: Atmospheric Chemistry and Greenhouse Gases, Climate Change 2001; Working Group 1: The Scientific Basis, edited by: Houghton, J., Ding, Y., Griggs, D., Noguer, M., van der Linden, P., and Xiaosu, D., Cambridge University Press, 2001.

Eva, H. D., Belward, A. S., De Miranda, E. E., Di Bella, C. M., GOND, V., Huber, O., Jones, S., Sgrenzaroli, M., and Fritz, S.: A Land Cover Map of South-America, Glob. Change Biol., 10, 731-744, doi:10.1111/j.1529-8817.2003.00774.x, 2004.

Fedorovich, E.: Modeling the atmospheric convective boundarylayer within a zero-order jump approach - an extended theoretical framework, J. Appl. Meteorol., 34, 1916-1928, 1995.

Galbally, I. E. and Kirstine, W.: The production of methanol by flowering plants and the global cycle of methanol, J. Atmos. Chem., 43, 195-229, 2002.

Ganzeveld, L., Valverde-Canossa, J., Moortgat, G. K., and Steinbrecher, R.: Evaluation of Peroxide Exchanges over Coniferous Forest in a Single-Column Chemistry-Climate Model, Atmos. Environ., 40, Suppl. 61, S68-S80, 2006.

Ganzeveld, L., Eerdekens, G., Feig, G., Fischer, H., Harder, H., Königstedt, R., Kubistin, D., Martinez, M., Meixner, F. X., Scheeren, H. A., Sinha, V., Taraborrelli, D., Williams, J., ViláGuerau de Arellano, J., and Lelieveld, J.: Surface and boundary layer exchanges of volatile organic compounds, nitrogen oxides and ozone during the GABRIEL campaign, Atmos. Chem. Phys., 8, 6223-6243, 2008,

http://www.atmos-chem-phys.net/8/6223/2008/.

Gebhardt, S., Colomb, A., Hofmann, R., Williams, J., and Lelieveld, J.: Halogenated organic species over the tropical South American rainforest, Atmos. Chem. Phys., 8, 3185-3197, 2008,

http://www.atmos-chem-phys.net/8/3185/2008/.

Geron, C., Guenther, A., Greenberg, J., Loescher, H., Clark, D., and Baker, B.: Biogenic Volatile Organic Compound Emissions from a Rain Forest in Costa Rica, Atmos. Environ., 36, 3793-3802, 2002.

Goldan, P. D., Kuster, W. C., Fehesenfeld, F. C., and Montzka, S. A.: Hydrocarbon measurements in the southeastern United States: The Rural Oxidants in the Southern Environment (ROSE) program 1990, J. Geophys. Res.-Atmos., 103, 31045-31056, 1995.

Goulden, M. L., Miller, S. D., da Rocha, H. R., Menton, M. C., de Freitas, H. C., Figueira, A. M. E. S., and de Sousa, C. A. D.: Diel and seasonal patterns of tropical forest $\mathrm{CO}_{2}$ exchange, Ecol. Appl., 14, S42-S54, 2004.

Greenberg, J. P. and Zimmerman, P.: Nonmethane hydrocarbons in remote tropical, continental, and marine atmospheres, J. Geophys. Res.-Atmos., 89, 4767-4778, 1984.

Greenberg, J. P., Guenther, A. B., Petron, G., Wiedinmyer, C., Vega, O., Gatti, L. V., Tota, J., and Fisch, G.: Biogenic VOC emissions from forested Amazonian landscapes, Global Biogeochem. Cy., 10, 651-662, 2004a.

Greenberg, J. P., Guenther, A. B., Petron, G., Wiedinmyer, C., Vega, O., Gatti, L. V., Tota, J., and Fisch, G.: Biogenic VOC emissions from forested Amazonian landscapes, Glob. Change Biol., 10,
651-662, 2004b.

Guenther, A., Nicolas Hewitt, C., Erickson, D., Fall, R., Geron, C., Graedel, T., Harley, P., Klinger, L., Lerdau, M., McKay, W. A., Pierce, T., Scholes, B., Steinbrecher, R., Tallamraju, R., Taylor, J., and Zimmerman, P.: A global model of natural volatile organic compound emissions, J. Geophys. Res., 100, 8873-8892, 1995.

Guenther, A.: The contribution of reactive carbon emissions from vegetation to the carbon balance of terrestrial ecosystems, Chemosphere, 49, 837-844, 2002.

Guenther, A., Karl, T., Harley, P., Wiedinmyer, C., Palmer, P. I., and Geron, C.: Estimates of global terrestrial isoprene emissions using MEGAN (Model of Emissions of Gases and Aerosols from Nature), Atmos. Chem. Phys., 6, 3181-3210, 2006, http://www.atmos-chem-phys.net/6/3181/2006/.

Guenther, A. B., Baugh, B., and Brasseur, G.: Isoprene emission estimates and uncertainties for the central African EXPRESSO study domain, J. Geophys. Res., 104, 30625-30639, 1999.

Gurk, C.: Untersuchungen zur Verteilung von Kohlendioxid in der Tropopausenregion., MSc, Diploma thesis, Johannes-Gutenberg University, Mainz, 2003.

Hamm, S., Hahn, J., Helas, G., and Warneck, P.: Acetonitrile in the troposphere - residence time due to rainout and uptake by the ocean, Geophys. Res. Lett., 11, 1207-1210, 1984.

Jacob, D. J.: Atmospheric budget of acetone, J. Geophys. Res., 107, 4100, doi:10.1029/2001JD000694, 2002.

Jöckel, P., Tost, H., Pozzer, A., Brühl, C., Buchholz, J., Ganzeveld, L., Hoor, P., Kerkweg, A., Lawrence, M. G., Sander, R., Steil, B., Stiller, G., Tanarhte, M., Taraborrelli, D., van Aardenne, J., and Lelieveld, J.: The atmospheric chemistry general circulation model ECHAM5/MESSy1: consistent simulation of ozone from the surface to the mesosphere, Atmos. Chem. Phys., 6, 50675104, 2006, http://www.atmos-chem-phys.net/6/5067/2006/.

Karl, T., Potosnak, M., Guenther, A., Clark, D., Walker, J., Herrick, J. D., and Geron, C.: Exchange processes of volatile organic compounds above a tropical rain forest: Implications for modeling tropospheric chemistry above dense vegetation, J. Geophys. Res.-Atmos., 109, D183306, doi:10.1029/2004JD004738, 2004.

Karl, T., Guenther, A., Yokelson, R. J., Greenberg, J., Potosnak, M., Blake, D. R., and Artaxo, P.: The tropical forest and fire emissions experiment: Emission, chemistry, and transport of biogenic volatile organic compounds in the lower atmosphere over Amazonia, J. Geophys. Res.-Atmos., 112(17), D18302, doi:10.1029/2007jd008539, 2007.

Kesselmeier, J. and Staudt, M.: Biogenic Volatile Organic Compounds (VOC): An Overview on Emission, Physiology and Ecology, J. Atmos. Chem., 33, 23-88, 1999.

Krejci, R., Ström, J., de Reus, M., Williams, J., Fischer, H., Andreae, M. O., and Hansson, H.-C.: Spatial and temporal distribution of atmospheric aerosols in the lowermost troposphere over the Amazonian tropical rainforest, Atmos. Chem. Phys., 5, 1527-1543, 2005, http://www.atmos-chem-phys.net/5/1527/2005/.

Kubistin, D., Harder, H., Martinez, M., Rudolf, M., Sander, R., Bozem, H., Eerdekens, G., Fischer, H., Gurk, C., Klüpfel, T., Königstedt, R., Parchatka, U., Schiller, C. L., Stickler, A., Taraborrelli, D., Williams, J., and Lelieveld, J.: Hydroxyl radicals in the tropical troposphere over the Suriname rainforest: 
comparison of measurements with the box model MECCA, Atmos. Chem. Phys. Discuss., 8, 15239-15289, 2008, http://www.atmos-chem-phys-discuss.net/8/15239/2008/.

Kuhn, U., Andreae, M. O., Ammann, C., Araújo, A. C., Brancaleoni, E., Ciccioli, P., Dindorf, T., Frattoni, M., Gatti, L. V., Ganzeveld, L., Kruijt, B., Lelieveld, J., Lloyd, J., Meixner, F. X., Nobre, A. D., Pöschl, U., Spirig, C., Stefani, P., Thielmann, A., Valentini, R., and Kesselmeier, J.: Isoprene and monoterpene fluxes from Central Amazonian rainforest inferred from towerbased and airborne measurements, and implications on the atmospheric chemistry and the local carbon budget, Atmos. Chem. Phys., 7, 2855-2879, 2007, http://www.atmos-chem-phys.net/7/2855/2007/.

Lee, W., Baasandorj, M., Stevens, P. S., and Hites, R. A.: Monitoring $\mathrm{OH}$-initiated oxidation kinetics of isoprene and its products using online mass spectrometry, Environ. Sci. Technol., 39, 1030-1036, doi:10.1021/es049438f, 2005.

Lelieveld, J. and Crutzen, P.: The role of clouds in tropospheric photochemistry, J. Atmos. Chem., 12, 229-267, 1991.

Lelieveld, J., Butler, T. M., Crowley, J., Dillon, T., Fischer, H., Ganzeveld, L., Harder, H., Kubistin, D., Lawrence, M. G., Martinez, M., Taraborrelli, D., and Williams, J.: Tropical forest sustains atmospheric oxidation capacity, Nature, 452, 737-740 2008.

Lindinger, W., Hansel, A., and Jordan, A.: On-line monitoring of volatile organic compounds at pptv levels by means of ProtonTransfer-Reaction Mass Spectrometry (PTR-MS): Medical Applications, food control and environmental research., Int. J. Mass Spectrom. and Ion Processes, 173, 191-241, 1998.

Marandino, C. A., De Bruyn, W. J., Miller, S. D., Prather, M. J., and Saltzman, E. S.: Oceanic uptake and the global atmospheric acetone budget, Geophys. Res. Lett., 32, L15806, doi:10.1029/2005GL023285, 2005.

Martin, C. L., Fitzjarrald, D., Garstang, M., Oliveira, A. P., Greco, S., and Browell, E.: Structure and growth of the mixing layer over the Amazonian rain forest, J. Geophys. Res., 93, 13611375, 1988.

Martinez, M., Harder, H., Kubistin, D., Rudolf, M., Bozem, H., Eerdekens, G., Fischer, H., Gurk, C., Klüpfel, T., Königstedt, R., Parchatka, U., Schiller, C. L., Stickler, A., Williams, J., and Lelieveld, J.: Hydroxyl radicals in the tropical troposphere over the Suriname rainforest: airborne measurements, Atmos. Chem. Phys. Discuss., 8, 15491-15536, 2008,

http://www.atmos-chem-phys-discuss.net/8/15491/2008/.

Martius, C., Höfer, H., Garcia, M. V. B., Römbke, J., and Hanagarth, W.: Litter fall, litter stocks and decomposition rates in rainforest and agroforestry sites in central Amazonia, Nutr. Cycl. Agroecosys., 68, 137-154, 2004.

Mayaux, P., Achard, F., and Malingreau, J.-P.: Global tropical forest area measurements derived from coarse resolution satellite imagery: a comparison with other approaches, Environ. Conserv., 25, 37-52, 1998.

Miyoshi, A., Hatakeyama, S., and Washida, N.: OH radicalinitiated photooxidation of isoprene: An estimate of global CO production, J. Geophys. Res., 99, 18787-18799, 1994.

Monson, R. K., Jaeger, C. H., Adams III, W., Driggers, E. M., Silver, G. M., and Fall, R.: Relationships among isoprene emission rate, photosynthesis, and isoprene synthase activity as influenced by temperature, Plant Physiol., 98, 1175-1180, 1992.
Montzka, S. A., Trainer, M., Goldan, P. D., Kuster, W. C., and Fehsenfeld, F. C.: Isoprene and its oxidation-products, methyl vinyl ketone and methacrolein, in the rural troposphere, J. Geophys. Res.-Atmos., 98, 1101-1111, 1993.

Nozière, B., Barnes, I., and Becker, K.-H.: Product study and mechanisms of the reactions of a-pinene and pinonaldehyde with $\mathrm{OH}$ radicals, J. Geophys. Res., 104, 23645-23656, 1999.

Paulson, S. E. and Seinfeld, J. H.: Development and evaluation of a photooxidation mechanism for isoprene, J. Geophys. Res., 97, 20703-20715, 1992.

Rinne, H. J. I., Guenther, A. B., Greenberg, J. P., and Harley, P. C.: Isoprene and monoterpene fluxes measured above Amazonian rainforest and their dependence on light and temperature, Atmos. Environ., 36, 2421-2426, 2002.

Roelofs, G.-J. and Lelieveld, J.: Tropospheric ozone simulation with a chemistry-general circulation model: Influence of higher hydrocarbon chemistry, J. Geophys. Res., 105, 22697-22712, 2000.

Ruppert, L. and Becker, K. H.: A product study of the $\mathrm{OH}$ radicalinitiated oxidation of isoprene: formation of $\mathrm{C}_{5}$-unsaturated diols, Atmos. Environ., 34, 1529-1542, 2000.

Scheeren, B., Becker, C., and Warsodikromo, T.: The climatology of Suriname with emphasis on the October 2005 GABRIEL campaign, Internal report Max Planck Institute for Chemistry, Mainz, Germany, 2007.

Schumann, U., Dörnbrack, A., and Mayer, B.: Cloud-shadow effects on the stracture of the convective boundary layer, Meteorol. Z., 11, 285-294, doi:10.1127/0941-2948/2002/0011-0285, 2002.

Siebesma, A. P., Christopher, B., Bretherton, S., Brown, A., Chlond, A., Cuxart, J., Duynkerke, P. G., Jiang, H., Khairoutdinov, M., Lewellen, D., Moeng, C.-H., Sanchez, E., Stevens, B., and Stevens, D. E.: A Large Eddy Simulation Intercomparison Study of Shallow Cumulus Convection, J. Atmos. Sci., 60, 1201-1219, 2003.

Sinha, V., Williams, J., Meyerhöfer, M., Riebesell, U., Paulino, A. I., and Larsen, A.: Air-sea fluxes of methanol, acetone, acetaldehyde, isoprene and DMS from a Norwegian fjord following a phytoplankton bloom in a mesocosm experiment, Atmos. Chem. Phys., 7, 739-755, 2007,

http://www.atmos-chem-phys.net/7/739/2007/.

Sinha, V., Williams, J., Crowley, J. N., and Lelieveld, J.: The Comparative Reactivity Method a new tool to measure total $\mathrm{OH} \mathrm{Re}$ activity in ambient air, Atmos. Chem. Phys., 8, 2213-2227, 2008, http://www.atmos-chem-phys.net/8/2213/2008/.

Spirig, C., Guenther, A., Greenberg, J. P., Calanca, P., and Tarvainen, V.: Tethered balloon measurements of biogenic volatile organic compounds at a Boreal forest site, Atmos. Chem. Phys., 4, 215-229, 2004, http://www.atmos-chem-phys.net/4/215/2004/.

Stickler, A., Fischer, H., Bozem, H., Gurk, C., Schiller, C., Martinez-Harder, M., Kubistin, D., Harder, H., Williams, J., Eerdekens, G., Yassaa, N., Ganzeveld, L., Sander, R., and Lelieveld, J.: Chemistry, transport and dry deposition of trace gases in the boundary layer over the tropical Atlantic Ocean and the Guyanas during the GABRIEL field campaign, Atmos. Chem. Phys., 7, 3933-3956, 2007, http://www.atmos-chem-phys.net/7/3933/2007/.

Stroud, C. A., Roberts, J. M., Goldan, P. D., Kuster, W. C., Murphy, P. C., Williams, E. J., Hereid, D., Parrish, U. D., Sueper, D., 
Trainer, M., Fehsenfeld, F. C., Apel, E. C., Riemer, D., Wert, B., Henry, B., Fried, A., Martinez-Harder, M., Harder, H., Brune, W. H., Li, G., Xie, H., and Young, V. L.: Isoprene and its oxidation products, methacrolein and methyl vinyl ketone, at an urban forested site during the 1999 Southern Oxidants Study, J. Geophys. Res., 106, 8034-8046, 2001.

Tang, Y., Carmichael, G. R., Uno, I., Woo, J.-H., Kurata, G., Lefer, B., Shetter, R. E., Huang, H., Anderson, B. E., Avery, M. A., Clarke, A. D., and Blake, D. R.: Impacts of aerosols and clouds on photolysis frequencies and photochemistry during TRACE-P: 2 . Three-dimensional study using a regional chemical transport model, J. Geophys. Res., 108, 8822, doi:10.1029/2002JD003100, 2003.

UNEP-WCMC, Forest Protection Analysis June 2000, online available at: http://www.unep-wcmc.org/forest/datasets_maps.htm, last access: November, 2006, 2000.

Valverde-Canossa, J.: Sources and Sinks or Organic Peroxides in the Planetary Boundary Layer, Ph.D., Johannes Gutenberg, Mainz, Germany, 2004.

Vilá-Guerau de Arellano, J., Kim, S.-W., Barth, M. C., and Patton, E. G.: Transport and chemical transformations influenced by shallow cumulus over land, Atmos. Chem. Phys., 5, 32193231, 2005,

http://www.atmos-chem-phys.net/5/3219/2005/.

Vilà-Guerau de Arellano, J.: Role of nocturnal turbulence and advection in the formation of shallow cumulus over land, Q. J. Roy. Meteorol. Soc., 133, 1615-1627, 2007.

Vilá-Guerau de Arellano, J., van den Dries, K., and Pino, D.: On inferring isoprene emission surface flux from atmospheric boundary layer concentration measurements, Atmos. Chem. Phys., 9, 3629-3640, 2009, http://www.atmos-chemphys.net/9/3629/2009/. von Kuhlmann, R., Lawrence, M. G., Pöschl, U., and Crutzen, P. J.: Sensitivities in global scale modeling of isoprene, Atmos. Chem. Phys., 4, 1-17, 2004, http://www.atmos-chem-phys.net/4/1/2004/.

Warneke, C., Karl, T., Judmaier, H., Hansel, A., Jordan, A., and Lindinger, W.: Acetone, methanol, and other partially oxidized volatile organic emissions from dead plant matter by abiological processes: Significance for atmospheric $\mathrm{HO}_{\mathrm{x}}$ chemistry, Global Biogeochem. Cy., 13, 9-17, 1999.

Warneke, C., Holzinger, R., Hansel, A., Jordan, A., Lindinger, W., Pöschl, U., Williams, J., Hoor, P., Fischer, H., Crutzen, P. J., Scheeren, H. A., and Lelieveld, J.: Isoprene and its oxidation products methyl vinyl ketone, methacrolein, and isoprene related peroxides measured online over the tropical rain forest of Surinam in March 1998, J. Atmos. Chem., 38, 167-185, 2001.

Williams, J., Pöschl, U., Crutzen, P. J., Hansel, A., Holzinger, R., Warneke, C., Lindinger, W., and Lelieveld, J.: An atmospheric chemistry interpretation of mass scans obtained from a proton transfer mass spectrometer flown over the tropical rainforest of Surinam, J. Atmos. Chem., 38, 133-166, 2001.

Williams, J., Holzinger, R., Gros, V., Xu, X., Atlas, E., and Wallace, D. W. R.: Measurements of organic species in air and seawater from the tropical Atlantic, Geophys. Res. Lett., 31(5), L23S06, doi:10.1029/2004GL020012 2004.

Williams, J., Yassaa, N., Bartenbach, S., and Lelieveld, J.: Mirror image hydrocarbons from Tropical and Boreal forests, Atmos. Chem. Phys., 7, 973-980, 2007, http://www.atmos-chem-phys.net/7/973/2007/.

Yienger, J. J. and Levy, I. H.: Global inventory of soil-biogenic $\mathrm{NO}_{\mathrm{x}}$ emissions, J. Geophys. Res., 100, 11447-11646, 1995. 